\title{
Thermochronological, petrographic and geochemical characteristics of the Combia Formation, Amagá basin, Colombia
}

\author{
Matthias Bernet ${ }^{1^{*}}$, Juliana Mesa Garcia ${ }^{2,3}$, Catherine Chauvel ${ }^{1,4}$ \\ and Maria Isabel Marín-Cerón², \\ ${ }^{1}$ Institut des Sciences de la Terre, CNRS, Université Grenoble Alpes, Grenoble, \\ France \\ ${ }^{2}$ Departemento de Geociencias, Universidad EAFIT, Medellín, Colombia \\ ${ }^{3}$ present address: Geology Department, University of Michigan, Ann Arbor, MI, USA \\ ${ }^{4}$ Université de Paris, Institut de Physique du Globe de Paris, CNRS,F-75005 Paris, \\ France \\ *corresponding author, email: matthias.bernet@univ-grenoble-alpes.fr, \\ ORCID: 0000-0001-5046-7520
}

\section{Abstract}

The Amagá basin between the Western and Central Cordilleras of the Northern Andes of Colombia host the Neogene volcanic and volcaniclastic Combia Formation. At this stage it is not clear how the formation of this unit is related to arc volcanism and which role the Nazca plate subduction beneath the western margin of South America plays. The timing, petrography and geochemical characteristics of Combia Formation rocks were studied in the western and eastern parts of the Amagá basin, in order to gain more information on the type of magma generation and volcanic activity that led to the deposition of the Combia Formation.

Apatite and zircon fission-track dating largely confirm a 12-6 Ma age for the deposition of the Combia Formation. Petrographic and major element analyses show that mainly trachy-andesite ignimbrites with a calc-alkaline composition were deposited in the western Amagá basin, whereas the volcanic rocks of the eastern 
32 Amagá basin are lava flow and fall-out deposits of basaltic andesites or of tholeiitic composition. Trace element and isotopic analyses show that slab dehydration and sediment melting were important in primary magma generation in the mantle wedge, but the primary magma was mixed with lower continental crustal melts, resulting in characteristic isotope signatures in the western and eastern Amagá basin. All this points to subduction driven arc volcanism with slab dehydration, sediment melting magma mixing.

\section{Introduction}

The late Paleogene to present-day magmatism of northwestern South America can be divided into four major phases of activity at about 24-20 Ma, 12-6 Ma, 6-3 Ma, and 3 Ma to the Present (e.g. Sierra, 1994; Toro et al., 1999; Gonzalez, 2001; Ramírez et al., 2006; Cediel et al., 2011; Pérez et al., 2013; Lesage et al., 2013). These different magmatic phases are related to the complex tectonic setting in which the Caribbean, Nazca and South American plates interact with each other (Fig. 1). The break-up of the Farallón plate into the Nazca and Cocos plates between 26 and 24 Ma (Marriner and Millward, 1984), the reorientation of subduction direction (Pardo-Casas and Molnar, 1987), and collision of the Panamá-Choco block with northwestern South America at about 25 Ma drove the first magmatic pulse (e.g. McCourt et al., 1984; Aspden et al., 1987; Kellogg and Vega, 1995; Trenkamp et al., 2002; Cediel et al., 2003; Lonsdale, 2005; Restrepo-Moreno et al., 2010; Farris et al., 2011). Second, since the late Paleogene the Nazca plate subduction zone was subjected to changes in subduction angle and direction over time, resulting in Miocene-Pliocene magmatic intrusions in the Western and Central Cordillera and 
deposition of the Combia Formation in the Amagá basin (e.g. Pardo-Casas and Molnar, 1987; Taboada et al., 2000; Cediel et al., 2003; Vargas and Mann, 2013). At the same time, subduction of the Caribbean plate beneath the northern (Caribbean) margin of South America caused isolated late Miocene-Pliocene volcanic activity in the Eastern Cordillera (e.g. Vargas and Mann, 2013), such as in the Vetas-California gold-mining district of the Santander Massif (Mantilla et al., 2013), or the Paipa-Iza complex 150 km to the north-east of Bogotá (Fig. 1; Padro et al., 2005; Bernet et al., 2016). Today the main volcanic activity in Colombia is focused on the Central 
and $\mathrm{Pb}$ isotope analyses. All this was done with the objective of a) characterizing and comparing the eastern and western volcanic deposits, and b) to better understand the mid-late Miocene evolution of the Nazca subduction zone magmatism manifested between the Western and Central Cordilleras.

\section{Geological setting}

The Northern Andes of northwestern South America consist in Colombia of the Western, Central and Eastern Cordilleras (Fig. 1). Each of these mountain belts reflects a particular part of the long-term evolution of the Northern Andes, which is characterized by magmatic episodes since the Precambrian, during the Triassic, Jurassic, Late Cretaceous, and since the late Paleogene/Neogene until today (Aspden et al., 1987). In general, these magmatic phases have been related to Farallón/Nazca plate subduction beneath the western margin of the South American plate (e.g. Marriner and Millward, 1984; McCourt et al., 1984; Cediel et al., 2003; Saenz, 2003; Restrepo-Moreno et al., 2009; Rodríguez et al., 2012). Accretion of tectonic blocks or terranes of oceanic affinity to the continental margin during the late Mesozoic and early Cenozoic did not cause Andean-type subduction volcanism, because of their relatively young age and high buoyancy preventing subduction (Cediel et al., 2003), and forcing surface uplift and the formation of the Western and Central Cordilleras during the Pre-Andean and Andean orogenies (e.g. Van der Hammen, 1960; Taboada et al., 2000; Cediel et al., 2003).

The present-day Andean volcanism is commonly divided into four volcanic zones, the Northern Volcanic Zone (NVZ), Central Volcanic Zone (CVZ), Southern Volcanic Zone (SVZ), and Austral Volcanic Zone (AVZ) (e.g. Thorpe and Francis, 1979; Thorpe et al., 1982; Stern, 2004; Marín-Cerón et al., 2019). These segments 
have been distinguished based on differences in petrographic features and geochemical signatures, and they are separated from each other by volcanic gaps (e.g. Thorpe and Francis, 1979; Stern, 2004). The NVZ is located in north-western South America and encompasses the region of present-day volcanism in the Northern Andes of Ecuador and Colombia.

Geology of the Amagá basin

The Amagá basin forms the northern part of the much larger Amagá-Cauca-

Patía basin located between the Western and Central Cordilleras of the Northern Andes in western Colombia (Fig. 1; Sierra and Marín-Cerón, 2011). Dextral strikeslip faulting along the Cauca and Romeral fault systems to the west and east respectively is responsible for development of the Amagá basin, which is tectonically a pull - apart basin (e.g. Cediel et al., 2003). Basin evolution started possibly during the Eocene (?) - Oligocene, with surface uplift and erosion of the Central Cordillera from the Late Cretaceous to Eocene and deposition of clastic sediments of the Lower Amagá Formation in the basin (e.g. Restrepo-Moreno et al., 2009). The Lower Amagá Formation is known for its quartz-rich sandstones and mainly sub-bituminous but locally anthracite grade coal (Silva et al., 2008; Blandon et al., 2008). The Lower Amagá Formation is separated from the Oligocene to Miocene Upper Amagá Formation by an unconformity and a change to a lithic arenite composition with sedimentary and metamorphic lithoclasts derived from the Central Cordillera (Paez Acuna, 2012). During the mid to late Miocene, subduction of the Nazca plate below the South American plate allowed the genesis of the Combia Formation in the Amagá basin (e.g. Grosse, 1926; Marriner and Millward, 1984; González, 2001; 
132 Therefore, the Upper Amagá Formation is overlain by volcanic and volcaniclastic deposits of the Combia Formation. Here we focus on the Cerro Amarillo section in the Eastern Amagá basin and the Anzá - Bolombolo and Le Metida Creek sections in the western Amagá basin.

\section{$\underline{\text { The Cerro Amarillo section }}$}

This section is located between the towns of Damasco and La Pintada (Fig. 2). It has a total thickness of $193 \mathrm{~m}$ and comprises 34 layers of welded tuff, pyroclastic and agglomerate breccia, lapilli tuff breccia, basalt and scoria (Fig. 3). The layers vary in thickness from a $20 \mathrm{~m}$ pyroclastic and agglomerate breccia to 0.3 $\mathrm{m}$ lapilli tuff breccia, both at the top (Mesa-Garcia, 2015). There is also a $19.2 \mathrm{~m}$ thick welded tuff at the bottom. However, it is most common to find layers of $1-7 \mathrm{~m}$ in thickness. The layers are characterized by a tabular geometry. No evidence of pinchout or lenses were observed in the outcrops. The bottom of the stratigraphic succession is mainly characterized by lava flows and welded tuff while, the top of the sequence mainly consists in coarse to very coarse grained pyroclastic flows. The bottom layers have a strike and dip of $S 05^{\circ} \mathrm{E} / 25^{\circ} \mathrm{SW}$ in average; towards the middle of the section the layers strike and dip $\mathrm{N} 70^{\circ} \mathrm{E} / 18^{\circ} \mathrm{SE}$. Finally the top breccia and lapilli tuff layers strike and dip N15 W/19SW. Many basalt and welded tuffs layers have randomly distributed vesicles and amygdules of variable size shapes, some are elongated indicating lava flow directions.

\section{The Anzá - Bolombolo section}

This section is also located on the western bank of the Cauca River (Fig. 2) between the villages of Anzá and Bolombolo. The stratigraphy of the $11.04 \mathrm{~m}$ thick 
succession consists of tuffs and lapilli tuffs in the lower part of the section, which are separated laterally from andesitic basalts and ash flow deposits by an erosional unconformity (Fig. 4; Grosse, 1926; González, 2001; Sierra and Marín-Cerón, 2011). In the upper part of the succession are a lapilli tuff breccia and a non-differentiated lava flow, which cover the underlying units and the unconformity. No particular sedimentary structures were observed at this location.

\section{The La Metida Creek section}

This section is located on the western bank of the Cauca River to the west of Bolombolo (Fig. 2). The Combia Formation crops out along the stream bed (e.g. González, 2001) and the exposed stratigraphic sequence has a thickness of $45 \mathrm{~m}$ and is composed of 33 layers of tuff, lapilli tuff, lapilli tuff breccia, pyroclastic flows and volcano-clastic sandstones (Fig. 5). Sedimentary structures found throughout the sequence include lenticular bedding, load structures, ripple lamination and crossbedding. The layers at the bottom are mainly grain-supported, whereas the top layers are matrix-supported. In addition, nodules and organic matter are commonly observed at the bottom of the section, and the middle section is characterized by bioturbation and fossilized plants (e.g. leaves). No such material was observed towards the top of the section.

\section{Analytical methods}

Apatite and zircon fission-track analyses

AFT analysis was done on two samples from the $A B$ section and six samples from the $M C$ section. In addition, ten samples of the $M C$ section were analyzed with 
the ZFT method. Unfortunately, the apatite and zircon yield of the CA section samples was too low for fission-track analyses.

Sample preparation and analyses were performed at the thermochronology laboratory of the Universidad EAFIT at Medellín and the ISTerre thermochronology laboratory at the Université Grenoble Alpes. Rock samples were crushed and sieved and heavy mineral fractions were separated using standard hydraulic, magnetic and heavy liquid separation techniques. The apatite crystals were mounted in epoxy and the zircon crystals in Teflon $\circledast$ sheets, polished and etched. Apatite grains were etched for 20 seconds at $21^{\circ} \mathrm{C}$ with $5.5 \mathrm{~mol} \mathrm{HNO}_{3}$, and zircons were etched at $228^{\circ} \mathrm{C}$ for $10-40 \mathrm{~h}$ in a $\mathrm{NaOH}-\mathrm{KOH}$ melt to reveal fission tracks. A white mica sheet was mounted as the external detector. All samples were irradiated with thermal neutrons at the FRM II reactor in Garching, Germany, with a nominal fluence of $8 \times 10^{15} \mathrm{n} / \mathrm{cm}^{2}$ for apatite and $0.5 \times 10^{15} \mathrm{n} / \mathrm{cm}^{2}$ for zircon, together with IRMM540R dosimeter glasses and Durango age standards for apatite, and IRMM541 dosimeter glasses and Buluk and Fish Canyon Tuff age standards for zircon. After irradiation external detectors were etched in $48 \% \mathrm{HF}$ for 18 min at $21^{\circ} \mathrm{C}$. Fission tracks were counted dry at $1250 \mathrm{x}$ using an Olympus BX51 microscope and the FTStage 4.04 system. Fission-track ages for each sample were calculated using the Binomfit software of Brandon (see Ehlers et al., 2005) and the RadialPlotter program of Vermeesch (2009).

Petrographic analyses

Petrographic analyses were performed on twenty samples, seven from the Cerro Amarillo section, three from the Anzá-Bolombolo section, and ten from the La Metida Creek section. Petrographic thin sections were prepared at Geoensayos 
S.A.S., Medellín, Colombia. Some of the pyroclastic samples had to be impregnated with epoxy, as these deposits were not well consolidated.

The samples were analyzed using an Olympus BX41TF petrographic microscope at the Geology department of EAFIT University. Modal analysis was performed counting 300 - 500 points per sample, using a point counter. The description of mineral assemblages and textures was done according to Mackenzie et al. (1984) and Ehlers (1987). The samples were classified using modal mineral composition and the QAP diagram of Streckeisen (1976) for volcanic rocks and based on the size of the material after Pettijohn (1975) for pyroclastic rocks.

\section{Geochemical analyses}

The rock samples collected in the field were crushed to $1 \mathrm{~mm}$ chips at the Laboratory of Solid Materials at EAFIT University. Two hundred grams per sample were separated thoroughly, choosing the rock chips that were the least weathered and geochemical analyses for major and trace elements were performed in the clean laboratory at the Institut des Sciences de la Terre (ISTerre) - Université Grenoble Alpes, France. Samples were finely powdered in an agate mortar previous to analyses, except for $\mathrm{Pb}$ isotope analysis for which rock chips were used directly. The sample preparation and analytical procedures were executed according to Chauvel et al. (2011), as summarized below.

For major elements, $50 \mathrm{mg}$ of powdered sample were dissolved in $800 \mu \mathrm{l}$ of concentrated $\mathrm{HNO}_{3}$ and 15 drops of concentrated $\mathrm{HF}$ and heated in a Savillex beaker for two days at $90^{\circ} \mathrm{C}$ on a hot plate. After cooling, $20 \mathrm{ml}$ of $\mathrm{H}_{3} \mathrm{BO}_{3}(25 \mathrm{~g} / \mathrm{l})$ were added to the solution to neutralize excess $\mathrm{HF}, 10 \mathrm{~g}$ of $\mathrm{HNO}_{3}$ and $250 \mathrm{ml}$ of milliQ water for further dilution. Five standards (BR 24, BEN, BHVO2, AGV-1 and 
230 BCR-1), a duplicate and a blank were as well prepared for analysis. The solutions were analyzed using Inductively Coupled Plasma Atomic Emission Spectroscopy (ICP AES) at ISTerre to determine the major element composition of each sample. Concentrations were obtained using the international rock standard BR to calibrate the signal and the values recommended by Chauvel et al. (2011). Loss on ignition (LOI) was calculated for all samples by heating one gram of sample at $1000^{\circ} \mathrm{C}$ for one hour.

Sixteen samples, five standards (BR 24, BEN, BHVO2, AGV-1 and BCR-1), three duplicates and one blank were analyzed for trace element contents. One hundred milligrams of samples and standards were dissolved in 20 drops of concentrated $\mathrm{HNO}_{3}$ and $3 \mathrm{ml}$ of $\mathrm{HF}$ for three days at $120^{\circ} \mathrm{C}$ in Savillex beakers. Samples were further taken up in $7 \mathrm{~N} \mathrm{HNO}_{3}$ and finally dissolved in $2 \% \mathrm{HNO}_{3}$ with traces of HF, to obtain a dilution factor of about 5000 (Chauvel et al., 2011). The sets of $\mathrm{Sr}$ samples, unleached and leached, were prepared following the same procedures as for the $\mathrm{Nd}$ samples and $\mathrm{Pb}$ samples, respectively. The samples were dissolved and conditioned in Savillex beakers. Rock chips were leached according to McDonough and Chauvel (1991), to eliminate as much as possible $\mathrm{Sr}$ and $\mathrm{Pb}$ superficial contamination. For $\mathrm{Nd}$ and unleached $\mathrm{Sr}$ isotopic measurements, $100 \mathrm{mg}$ of sample were dissolved using $\mathrm{HNO}_{3}$ and $\mathrm{HF}$ and isolated using the same procedure as Chauvel et al. (2011). For $\mathrm{Pb}$ and leached $\mathrm{Sr}, 1 \mathrm{~g}$ of rock chips was leached prior to dissolution using $\mathrm{HCl}$ and then isolated as in Chauvel et al. (2011). 
255 ENS Lyon, France, while Sr isotopic ratios were measured using a Thermo Scientist

256 Triton MS at the University of Brest, France.

257

258 Results

259 Fission-track results

260 Anzá - Bolombolo section

The tuff layer at the bottom of the Anzá-Bolombolo section (sample JJ22) has an AFT central age of $8.4 \pm 3.1 \mathrm{Ma}$, and the pyroclastic flow sampled towards the top

263

264

265

266

267

268

269

270

271

272

273

274

275

276

277

278 of the section (sample JJ13) has an AFT central age of $7.9 \pm 1$ Ma (Table 1; see the supplementary data for individual grain ages and radial plots of all samples). The combined Combia Formation AFT data are shown in a radial plot in Figure 6A with a central age of $8.6 \pm 1.4 \mathrm{Ma}$ based on 302 grain ages.

\section{$\underline{\text { La Metida Creek section }}$}

In total six samples were analyzed with the AFT method and ten with the ZFT method. AFT central ages range between $15.9 \pm 11.1$ and $5.1 \pm 2.5 \mathrm{Ma}$. Nonetheless, inherited single grains with apparent cooling ages of between 374 and 49 Ma can also be observed in all samples (Table 1). Zircon crystals were mainly found in the middle and bottom of the La Metida Creek section. The euhedral to subhedral zircon crystals range in color from colorless, yellow, pink to red. The ZFT central ages are

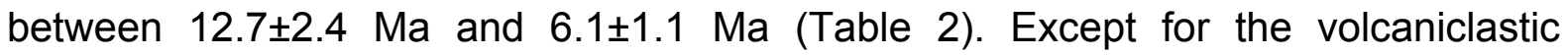
sandstone sample (JJ6), no strong evidence exist of contamination with inherited zircons derived from surrounding country rock (see the supplementary data for individual grain ages and radial plots of all samples). The combined Combia 


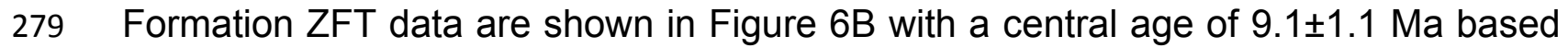
on 346 grain ages.

Petrographic results

283

284

285

286

287

\section{Cerro Amarillo section}

In general, the seven samples analyzed for this section share similar characteristics being hypocrystalline, porphyritic rocks. The mineral assemblage is represented by plagioclase + pyroxene \pm amphibole \pm olivine (Table 3 ). Other minerals present in the samples are secondary calcite, biotite and opaque minerals. The rock fragments found in the ignimbrites are mainly basalts (aphanitic textures and volcanic glass) or andesites (plagioclase crystals in volcanic glass). Some of these fragments are fractured. There is also evidence of oxidation and sericitization, even though carbonate minerals are the main alteration product in these samples.

The ignimbrites are dominated by crystals and rock fragments ranging from $55-70 \%$, whereas the two basalt samples have different percentage relationships between the matrix and phenocrysts, CA - 14 rich in crystals and CA - 18 rich in matrix. The crystal and/or rock fragments are in-equigranular, which is observed in the presence of seriate, glomeroporphyritic, poikilitic, and interstitial textures.

Overgrowth textures such as skeletal, corona and crystal zoning are also found in the samples, mainly in the ignimbrites. The crystals have subhedral to anhedral shapes in most samples; euhedral-shaped crystals are rare or unable to identify due to alteration. The matrix is generally altered to secondary calcite, but in some cases a non-altered volcanic glass composition is observed with some embedded microlites of plagioclase and less common pyroxene. 

Amarillo section plot in the basalt/andesite field of the classification diagram of Streckeisen (1976) shown in Figure 7A. Color plates of thin section photographs are given in the supplementary data archive.

307

The analyzed samples are hypocrystalline, un-equigranular volcanic rocks.

The mineral assemblages are mainly plagioclase + pyroxene (Table 3$)$. The matrix consists of volcanic glass. Other rock components are spherulites, found in samples $A B-6$ and $A B-7$, and olivine, found in sample $A B-6$. These samples are located to the east of the unconformity described in the stratigraphic section. The samples are characterized by having skeletal and crystal zoning overgrowth, spherulites and vesicular textures. The lava flows can be classified as basalt/andesite in the Streckeisen (1976) diagram (Fig. 7a), and the pyroclastic flow deposits as crystal tuffs after Pettijohn (1975), as shown in Figure 7b. Color plates of thin section photographs are given in the supplementary data.

\section{La Metida Creek section}

Nine samples from this section mainly plot in the crystal tuff field of the Pettijohn (1975) classification (Fig. 7b). Only one sample (QML - 9) is defined as tuffaceous sandstone because of the presence of cross-bedding in the layer. Petrographic characteristics of all samples are similar and the classification as pyroclastic and epiclastic rocks is based on sedimentary structures observed in the field. The mineral assemblage is mainly plagioclase + pyroxene. Some amphiboles are present at the bottom layers. 
The sampled rocks are mainly hypocrystalline due to the presence of phenocryst, and microlites in the matrix. The minerals have un-equigranular and seriate fabrics. In general, skeletal textures are found in all analyzed samples. Other common textures are glomero-porphyritic and crystal zoning, although the latter is not present in the samples analyzed from the middle section of the La Metida Creek section. Similar to the Anzá-Bolombolo section spherulites are found in the samples from the bottom layers. Color plates of thin section photographs are given in the supplementary data.

\section{Geochemical results}

Mayor element analyses of 16 samples are presented in Table 4. Loss on ignition (LOI) is generally below $3 \%$. For the Cerro Amarillo section samples, $\mathrm{SiO}_{2}$ contents range between 51 and $53 \mathrm{wt} \%$; they plot in the tholeiitic field of the AFM diagram (Fig. 8A) and correspond to basaltic andesite according to Figures 8B. Samples coming from the Anza-Bolombolo area have slightly higher $\mathrm{SiO}_{2}$ content at about 56 wt\%; they plot in the alkaline field in Fig. $8 \mathrm{~A}$ and correspond to trachyandesites in Fig. 8B.

Trace element contents of all samples are given in Table 5 and plotted in primitive mantle-normalized spider diagrams in Fig. 9A. The Cerro Amarillo samples display an enrichment in large-ion lithophile elements ( $\mathrm{Rb}, \mathrm{Ba}, \mathrm{Cs}, \mathrm{Sr})$ and a strong depletion in $\mathrm{Nb}$ and Ta. The Anzá-Bolombolo samples are even more enriched in $\mathrm{Rb}, \mathrm{Ba}, \mathrm{Cs}$ and $\mathrm{Sr}$, and with similar depletion in $\mathrm{Nb}$ and $\mathrm{Ta}$ (Fig. 9A). The main difference between the Cerro Amarillo and Anzá-Bolombolo samples is the $\mathrm{Li}$ enrichment of the Anzá-Bolombolo section samples. Samples from both sections are enriched in Light Rare Earth Elements (LREE) relative to the Heavy Rare Earth 
353 Elements (HREE) (Fig. 9B) with a stronger fractionation in the Anzá-Bolombolo section samples. No significant Eu anomaly exists for all samples.

\section{$\underline{\mathrm{Nd}, \mathrm{Sr} \text {, and } \mathrm{Pb} \text { isotope compositions }}$}

$\mathrm{Nd}, \mathrm{Sr}$, and $\mathrm{Pb}$ isotope analyses of all samples are given in Table 6. Strontium isotopic ratios measured on leached and unleached samples are similar within errors. ${ }^{87} \mathrm{Sr} /{ }^{86} \mathrm{Sr}$ ratios range from 0.703862 to 0.703931 for the Cerro Amarillo section samples, but are higher at about 0.70417 for the Anzá-Bolombolo section samples (Figure 10A). ${ }^{143} \mathrm{Nd} /{ }^{144} \mathrm{Nd}$ ratios vary between 0.51292 and 0.51298 for the

Cerro Amarillo section samples, and are somewhat lower at 0.51290 for the $A B$ section samples (Figure $10 \mathrm{~B}$ and $\mathrm{C}$ ). Finally, the Cerro Amarillo section samples define a small range in $\mathrm{Pb}$ isotopic ratios $\left({ }^{208} \mathrm{~Pb} /{ }^{204} \mathrm{~Pb}: 38.68\right.$ to $38.80,{ }^{207} \mathrm{~Pb} /{ }^{204} \mathrm{~Pb}$ : 15.61 to 15.62 and ${ }^{206} \mathrm{~Pb} /{ }^{204} \mathrm{~Pb}: 18.91$ to 19.07$)$, and the Anzá Bolombolo section samples fall in the middle of the range (Figure 11a and b)

\section{Discussion}

Constraints from low-temperature thermochronology

The AFT and ZFT data presented in this study can in principle be used for constraining the age of deposition of the volcanic and volcaniclastic deposits of the

374 Combia Formation (Kowallis et al., 1986; Bernet et al., 2016). The AFT and ZFT data central age values ranging from $15.9-5.1 \mathrm{Ma}$ for AFT and 12.7 - 6.1 Ma for ZFT, bracket the known 12-6 Ma age of Combia Formation volcanic activity (e.g. Leal377 Mejía, 2011). Our fission-track data highlight two important aspects that are 
challenging in dating relatively young volcanic and volcaniclastic deposits with the fission-track method. As to be expected the ZFT data correspond more closely to the known 12-6 Ma age range determined from zircon U-Pb analyses (Leal-Mejía, 2011), because of the higher $U$ concentration and the better track counting statistics resulting in higher precision results. The AFT data suffer under the very low (in general $<10 \mathrm{ppm}) \cup$ concentration of the apatites in the Combia Formation. As can been seen in the single grain data provided in the supplementary data archive, many apatite grains are zero-track grains, resulting in a very high single grain age uncertainty, as the induced track counts also tend to be because of the low $U$ concentrations.

In addition, dealing with volcanic and particularly volcaniclastic deposits the risk of contamination with apatites and zircons recycled from the country rock is high, and has been shown to be the case for certain volcanic deposits of the Paipa-Iza volcanic complex (Bernet et al., 2016). Here we also think that zircons with $>12 \mathrm{Ma}$ apparent cooling ages were most likely recycled from the Amagá Formation (Piedrahita et al., 2017). Pre-Miocene cooling ages are common in apatites of the which has previously been proposed based on stratigraphic position and whole rock 
Marriner and Millward, 1984; González, 2001, Pérez, 2005; Ramírez et al., 2006; Leal-Mejía, 2011).

\section{Shallow-level processes prior to eruption}

The results presented in this study indicate that there are two different petrographic trends among the Combia Formation rocks. In general, the rocks have porphyritic textures, and plagioclase is one of the main mineral components, both as phenocrysts and microlites. Similar results have been reported by Marriner and Millward (1984), López et al. (2006) and Ramírez et al. (2006).

The matrix for most samples is comprised of volcanic glass with microlites of plagioclase and to a lesser extent pyroxene. Devitrification of the volcanic glass matrix is common in the samples. The samples show evidence of alteration (e.g. secondary calcite, oxidation, argillitization) which may indicate metasomatic to surficial processes related to hydrothermal alterations and mineralization processes in the hypabyssal porphyries of the study area (e.g. Tassinari et al., 2008; LealMejía, 2011; Lesage et al., 2013; Uribe-Mogollón, 2013).

All samples show disequilibrium textures such as skeletal, sieve and spherulitic textures, embayments, reaction rims, coronas and crystal zoning. These textures are attributed to different conditions and magmatic processes such as pressure variations, zoned magma chambers, decompression, magma mixing, phenocrysts recycling and fractional crystallization (e.g. Nixon and Pearce, 1987; Nelson and Montana, 1992; Singer et al., 1995; Perugini et al., 2003; Aldanmaz, 2006; Maro and Remesal, 2011). Thus, our petrographic results favor mainly magma mixing and fractional crystallization to be the main causes for disequilibrium in the magma chamber. 
Magma genesis

Magmatic arcs are the result of subduction of oceanic crust beneath continental crust and this complex setting has impact on magmatic processes such as partial melting, fractional crystallization, changes in pressure and temperature, sediment melting, dehydration, and decarbonation (e.g. Rollinson, 1993; Albarade, 1995; White, 2013). In addition, fluids added to magma play an important role, as fluids allow the transport of incompatible elements from the subducted oceanic basalt and sediments to the magma, leading to enrichment in specific mobile elements and modifying the isotopic composition of the asthenospheric magma source (Tatsumi, 2005; Tatsumi and Stern, 2006; Tatsumi and Takahashi, 2006; Nakamura et al., 1985).

Our new geochemical data for the Cerro Amarillo area are generally similar to what was previously published by Marriner and Millward (1984) and by Ordoñez (2001). Major elements allow identification of a tholeiitic trend in the samples from the eastern Amagá basin while the samples from the western Amagá basin follow a calc-alkaline trend (Fig. 8A). Both magma suites have been previously recognized at other sampling sites of the Combia Formation (Fig. 8A; e.g. Álvarez, 1983; Marriner and Millward, 1984; Ordoñez, 2001; Leal-Mejía, 2011). With $\mathrm{SiO}_{2}$ contents between $47-59$ wt\% our Cerro Amarillo samples plot in the basaltic andesite field of Fig. 8B and the samples from Anzá Bolombolo plot in the trachy-andesite field of LeMaitre et al. (1989) and Cox et al. (1979) (Fig. 8B). For comparison, published data for the Combia Formation are also shown in this figure. It appears clearly that the $A B$ section samples from the western Amagá basin are much more alkaline than others (Fig. 8B), and that samples from both sections have lower $\mathrm{SiO}_{2}$ contents than the 
452 volcanic rocks of the 24-20 Ma magmatic phase and most of the 17-9 Ma magmatic 453 phase rocks analyzed by Leal-Mejía (2011). Despite these differences, so far no precise division of the basin with respect to the magmatic suites can be given at the moment, and more detailed mapping and geochemical analyses are necessary. The trace elements provide clear evidence of a subduction-related geochemical signature, with $\mathrm{Nb}$ and Ta depletion (e.g. Wilson, 1989; White, 2013). Samples also all have very high $\mathrm{Ba}, \mathrm{U}, \mathrm{Pb}$ and $\mathrm{Sr}$ contents as already noticed for older samples from the Combia Formation (Fig. 9C, Leal-Mejía, 2011 data summarized in Marín-Cerón et al., 2019). Medium to slightly elevated Ba/Th values (a proxy for slab dehydration Fig. 9E; Labanieh et al., 2012) characterize the Cerro Amarillo samples from the eastern Amagá basin, whereas the $A B$ samples of the western Amagá basin have low ratio consistent with a sediment melting trend.

In general, the trace element results of the Amagá basin resemble those of the northern volcanic zone (NVZ) of the Andes, as summarized in Marín-Cerón et al. Marriner and Millward, 1984).

The REE patterns of samples from the Anza Bolombolo and Cerro Amarillo sections are somewhat different, with higher fractionation in the former group (Fig. $9 b)$. In comparison to the REE spectra of the 17-6 Ma porphyritic intrusions and recent volcanism, the Combia Formation shows a pattern closer to the latest stage of volcanic activity (Fig. 9D; data from Leal-Mejía (2011), summarized by Marín-Cerón et al. (2019)). The difference in the slope of the REE patterns of eastern and western Amagá basin samples suggest differences in terms of magma formation, most probably during melting processes in the mantle source. Overall, the absence of Eu 
477 anomaly suggests that melting occurred relatively deep, below the plagioclase 478 stability level ( 40 km depth).

\section{Magma source composition}

Combining trace element data with isotopic data can help understanding the origin of magmas and the potential role of subducted slab addition to the mantle wedge (e.g Tatsumi, 2005; Tatsumi and Stern, 2006). The Cerro Amarillo and AnzáBolombolo samples have medium to slightly elevated $\mathrm{Sr} / \mathrm{Th}$ and rather low ${ }^{87} \mathrm{Sr} /{ }^{86} \mathrm{Sr}$ ratios (Fig. 10A), indicating transfer of elements from the subducted slab byNVZ aqueous fluids. Because no systematic difference in ${ }^{87} \mathrm{Sr} /{ }^{86} \mathrm{Sr}$ is observed between leached and unleached samples (Table 6), post-emplacement alteration can be excluded, and the measured ratios can be considered as representative of the magma source (e.g. Tamura and Nakamura, 1996; Shibata and Nakamura, 1997). Similarly, the large range of $\mathrm{Ba} / \mathrm{Th}$ at almost constant ${ }^{143} \mathrm{Nd} /{ }^{144} \mathrm{Nd}$ indicates addition of $\mathrm{Ba}$ through slab dehydration (Fig. 10B), with a stronger effect in the eastern Amagá basin than in the western part of the basin. In a ${ }^{87} \mathrm{Sr} /{ }^{86} \mathrm{Sr}$ vs ${ }^{143} \mathrm{Nd} /{ }^{144} \mathrm{Nd}$ isotopic space (Fig. 10C), the Amaga basin samples fall as expected within the field defined by the NVZ (see compilation of Marín-Cerón et al., 2019). It is worth noting that the Amaga Basin samples correspond to the most depleted part of the isotopic range observed along the Andes, suggesting limited crustal contamination during magma ascent and/or limited contribution of subducted sedimentary material to the mantle wedge. It is also worth noting that the Anzá-Bolombolo samples have slightly more enriched isotopic characteristics than the Cerro Amarillo samples, a feature consistent with the difference seen in Figure 9E since sediment addition tends to lower the $\mathrm{Nd}$ isotopic composition and increase the $\mathrm{Sr}$ isotopes. 
Lead isotopes provide complementary and useful information. As was the case for $\mathrm{Sr}$ and $\mathrm{Nd}$ isotopic data, the Amaga basin samples fall in the field defined by the northern volcanic zone and differ drastically from fields defined by central and southern volcanic zones (Fig. 11A) (see compilations made by Marín-Cerón, 2007 and Marín-Cerón et al., 2010; 2019). The rather radiogenic values of $\mathrm{Pb}$ isotopes for the northern volcanic zone have been interpreted as being due either to an enriched mantle reservoir or to continental crust assimilation. The enriched mantle hypothesis was suggested by Rodríguez-Vargas et al. (2005) on the basis of the $\mathrm{Nd}$ and $\mathrm{Sr}$ isotopic characteristics of xenoliths from the Mercaderes region in SW Colombia. The authors invoked the potential involvement of magma material coming from the Galapagos plume, but such influence under the Amaga basin seems quite unlikely given the distance between the SW Colombian arc and the Galapagos (>450 km, Pedersen and Furnes, 2001). However, the Amaga Basin samples analyzed in this study provide new information because they define a tight correlation in ${ }^{208} \mathrm{~Pb} /{ }^{204} \mathrm{~Pb}$ vs ${ }^{206} \mathrm{~Pb} /{ }^{204} \mathrm{~Pb}$ space (see Fig 11B). Such linear array implies the involvement and mixture of two endmembers whose compositions remain unchanged during the entire volcanic sequence. The enriched end-member seems to correspond to the local lower continental crust (see Fig. 11B) while the less radiogenic endmember is more ambiguous. Following Marin-Ceron's model (2019), this 'depleted' endmember could correspond to the mantle wedge whose composition would be affected by the presence of material originating from the subducted slab (see Fig. 11B). Nonetheless, there might be differences in the subduction mechanisms, proportion of end-members interaction, and magma source evolution between magmatism at 12 $6 \mathrm{Ma}$ and magmatism at $3 \mathrm{Ma}$ - present, despite assuming the same end-members. In summary, magma was generated by slab dehydration, sediment melting and 
527 interactions with the LCC, resulting in the mixing of at least two end-member 528 sources. Due to differences in depth of melting and other magmatic processes (AFM and MASH), as shown in Figure 12, the late Miocene volcanic rocks of the western and eastern Amagá basin show distinct petrologic and geochemical signatures.

\section{Conclusions}

The late Miocene volcanic and volcanoclastic Combia Formation of the Amagá basin between in the Central and Western Cordillera developed above the Nazca plate subduction zone in western Colombia. Volcanic and volcaniclastic rocks of the Combia Formation are characterized by a sequence of ignimbrites and lava flows of tholeiitic affinity at the bottom and pyroclastic flows to the top of the formation in the eastern Amaga basin and a succession of pyroclastic and epiclastic flows with calc-alkaline affinity in the western Amagá basin. Using apatite and zircon fission-track dating the timing of volcanic activity during the deposition of the Combia Formation was confirmed between 12 and $6 \mathrm{Ma}$.

Trace element, $\mathrm{REE}$ and $\mathrm{Nd}, \mathrm{Sr}$ and $\mathrm{Pb}$ isotopic analyses show that the surface weathering did not modify the geochemical signatures and that the geochemical composition of the samples results of several magmatic processes including slab dehydration and sediment melting to form the primary magma in the mantle wedge and mixing of this primary magma with lower continental crustal before eruption. In contrast, contamination by upper crustal rocks could not be detected. Finally, the new geochemical results confirm that volcanism in the Combia area between 12 and 6 Ma was similar to what is known about the NVZ of the Andes in South America. 


\section{Acknowledgements}

554 We acknowledge support of this study from ECOS-NORD/Colciencias/ICETEX 555 project C12U01 of M. Bernet and M.I. Marín-Cerón, as well as a BQR SUD grant at 556 ISTerre, awarded to M. Bernet. We thank Wilton, Francois Senebier and Francis 557 Coeur for help with sample preparation and mineral separation.

558

559 
561 Albarade, F. 1995. Introduction to geochemical modelling. Cambridge University 562 Press. 543 pp.

563

Aldanmaz, E. 2006. Mineral - chemical constraints in the Miocene calc-alkaline and shoshonitic volcanic rocks of Western Turkey: Disequilibrium phenochryst assemblages as indicators of magma storage and mixing conditions. Turkish Journal of Earth Sciences. 15: $47-73$.

Álvarez, A. 1983. Geología de la cordillera Central y el Occidente colombiano y petroquímica de los intrusivos granitoides Mesocenozoicos. Boletín Geológico. 26: $175 \mathrm{pp}$.

Aspden, J.A., McCourt, W.J., and Brook, M., 1987. Geometrical control of subduction-related magmatism: the Mesozoic and Cenozoic plutonic history of Western Colombia. Journal of the Geological Society, London. 144: 893 - 905.

Barret, T.J. 1983. Strontium- and lead-isotope composition of some basalts form Deep Sea Drilling Project Hole 504B, Costa Rica Rift, Legs 69 and 70. In Cann, J.R., Langseth, M.G., Honnorez, J., VonHerzen, R.P., White, S.M., et al., Init. Repts. DSDP, 69. Washington (U.S. Govt. Printing Office). $643-650$.

Barret T. J., Taylor P. N., Lugowski J. 1987. Metalliferous sediments from DSDP leg 92: the East Pacific Rise transects. Geochim. Cosmochim. Acta. 46:651 - 666.

Bernet, M., Uruena, C., Amaya, S.,Pena, M.L., 2016. New thermo- and geochronological constraints on the Pliocene-Pleistocene eruption history of the Paipa-Iza volcanic complex, Eastern Cordillera, Colombia, Journal of Volcanology and Geothermal Research , 327:299-309. 
583 Blandon, A., Parra, N., Gorin, G.E., Arango, F. 2008. Adapting palynological 584 preparation methods in subbituminous and bituminous coals from Colombia to 585 improve palynofacies and hydrocarbon source rock evaluations. International Journal 586 of Coal Geology, 73:99-114.

587 Calle, B., González, H. 1980. Geología y Geoquímica de la Plancha 166, Jericó. 588 Informe no. 1822. Medellín. INGEOMINAS. 232 pp.

589 Cediel, F., Shaw, R.P., Caceres, C. 2003. Tectonic assembly of the Northern 590 Andean Block, in C. Bartolini, R. T. Buffler, and J. Blickwede, eds., The Circum-Gulf 591 of Mexico and the Caribbean: Hydrocarbon habitats, basin formation, and plate 592 tectonics.- AAPG Memoir 79: 815-848.

593 Cediel, F., Leal-Mejía, H., Shaw, R.P., Melgarego, J.C., Restrepo-Pace, P.A. 2011. 594 Petroleum Geology of Colombia: Regional Geology of Colombia. ANH - Colombia. 595 1: $220 \mathrm{pp}$.

596 Chauvel, C., Bureau, S., Poggi, C. 2011. Comprehensive Chemical and Isotopic 597 Analyses of Basalt and Sediment Reference Materials. Geostandards and 598 geoanalytical research. 35 (1): $125-143$.

599 Chiaradia, M., Fontbote, L. 2002. Lead isotope systematics of Late Cretaceous 600 Tertiary Andean arc magmas and associated ores between $8^{\circ} \mathrm{N}$ and $40^{\circ} \mathrm{S}$ : evidence 601 for latitudinal mantle heterogeneity beneath the Andes. Terra Nova. 14 (5): 337 602342.

603 Cox, K.G., Bell, J.D., Pankhurst, R.J. 1979. The Interpretation of Igneous Rocks: 604 London, George Allen \& Unwin. 464 pp. 
605

606

607

608

609

610

611

612

613

614

615

616

617

618

619

620

621

622

623

624

625

626

627

Dasch, E.J. 1981. Lead isotopic composition of metalliferous sediments from the Nazca Plate. Mem. Geol. Soc. Am. 154: 199 - 209.

Davidson, J.P., de Silva, S.L. 1992. Volcanic rocks from the Bolivian Altiplano: Insights into crustal structure, contamination, and magma genesis in the central Andes. Geology. 20: $1127-1130$.

de Silva, S. 1991. Styles of zoning in Central Andean ignimbrites-insights into magma chamber processes: In: Andean magmatism and its tectonic setting. Special paper 265: $217-232$.

DePaolo, D. J. (1981). Trace-element and isotopic effects of combined wallrock assimilation and fractional crystallisation. Earth and Planetary Science Letters 53, 189-202.

Ehlers, E.G. 1987. Optical Mineralogy: Vol. 2. Mineral Descriptions. Blackwell Scientific Pub. Palo Alto. 286 pp.

Ehlers, T.A., Chaudhri, T., Kumar, S., Fuller, C., Willett, S.D., Ketcham, R., Brandon, M.T. 2005.Computational tools for low-temperature thermochronometer interpretation. In: Reiners, P.W., Ehlers, T.A. (Eds.), Low-temperature Thermochronology. Techniques, Interpretations and Applications. Reviews in Mineralogy and Geochemistry, Mineralogical Society of America 58:pp. 589-622. http://dx.doi.org/10.2138/rmg.2005.58.22.

Evensen, N. M., Hamilton, P. J., O"Nions, R. K. 1978. Rare-earth abundances in chondritic meteorites. Geochimica et Cosmochimica Acta. 42: 1199 - 1212.

Farris, D.W., Jaramillo, C., Bayona, G., Restrepo-Moreno, S.A., Montes, C., Cardona, A., Mora, A., Speakman, R.J., Glascock, M.D., Valencia, V. 2011. 
628 Fracturing of the Panamanian Isthmus during initial collision with South America. 629 Geology. 39 (11): $1007-1010$.

630 Frey, F.A., Gerlach, D.C., Hickey, R.L., López-Escobar, L., Minizaga-Villavicencio, F. 631 1984. Petrogenesis of the Laguna del Maule volcanic complex, Chile $\left(36^{\circ} \mathrm{S}\right)$. Contrib. 632 Mineral Petrol. 88: 133 - 149.

633 González, H. 2001. Memoria Explicativa del Mapa Geológico del Departamento de 634 Antioquia. Escala 1:400.000. Medellín, INGEOMINAS. 240 pp.

635 Grosse, E., 1926. Estudio Geológico del Terciario carbonífero de Antioquia en la 636 parte occidental de la Cordillera Central de Colombia: Berlín, Verlag Von Dietrich 637 Reimer. $361 \mathrm{pp}$. Halliday, A.N., Lee, D-C., Tommasini, S., Davies, G.R., Paslick, C.R., Fitton, J.G., James, D.E. 1995. Incompatible trace elements in OIB and MORB and source enrichment in the sub-oceanic mantle. Earth Planet. Sci. Lett. 133: $379-395$.

Harmon, R.S., Barreiro, B., Moorbath, S., Hoefs, J., Francis, P.W., Thorpe, R.S., Deruelle, B., McHugh, J. and Viglino, J.A. 1984. Regional O-, Sr-, and Pb- isotope relationships in late Cenozoic calc-alkaline lavas of the Andean Cordillera: Journal of the Geological Society. 141 (5): $803-822$.

Hawkesworth, C.J., Powell, M. 1980. Magma genesis in the Lesser Antilles island arc. Earth and Planetary Science Letters. 51: 297 - 308.

Hawkesworth, C.J., Norry, M.J., Roddick, J.C., Baker, P.E., Francis, P.W., Thorpe, R.S., 1979. $143 \mathrm{Nd} / 144 \mathrm{Nd}, 87 \mathrm{Sr} / 86 \mathrm{Sr}$, and incompatible trace element variations in calc-alkaline andesitic and plateau lavas from South America. Earth Planet. Sci. Letters. 42: $45-57$. 
651 Hemming S.R, McLeannan, S.M. 2001. Pb isotopic compositions of modern deep 652 sea turbidites. Earth Planet. Sci. Let. 184, 489 - 503.

653 Hickey, R.L., Frey, F.A., Gerlach, D.C. López-Escobar, L. 1986. Multiple sources for 654 basaltic arc rocks from the southern volcanic zone of the Andes $\left(34^{\circ}-41^{\circ} \mathrm{S}\right)$ : Trace 655 element and isotopic evidence for contributions from subducted oceanic crust, 656 mantle, and continental crust. J. Geophys. Res. 91 (B6): 5963 - 5983.

657

Hildreth, W.; Moorbath, S. 1988. Crustal contribution to arc magmatism in the Andes 658 of central Chile. Contribution to Mineralogy and Petrology. 98: 455 - 489. Irvine, T.N., Baragar, W.R.A. 1971. A guide to the chemical classification of the common volcanic rocks: Canadian Journal of Earth Sciences. 8 (5): 523 - 548.

Ishikawa T., Nakamura E. 1994. Origin of the slab component in arc lavas from 662 across-arc variation of B and Pb isotopes. Nature. 370: 205 - 208.

James, D.E. 1982. A combined $\mathrm{O}, \mathrm{Sr}, \mathrm{Nd}$, and $\mathrm{Pb}$ isotopic and trace element study 664 of crustal contamination in central Andean lavas: I. Local geochemical variations. Earth and Planetary Science Letter. 57: 47 - 62.

666 James, D.E., Brooks, C., Cuyubamba, A. 1976. Andean Cenozoic volcanism: 667 Magma genesis in the light of strontium isotopic composition and trace-element geochemistry. Geol. Soc. Amer. Bull. 87: 592 - 600 .

Jaramillo, J. M., 1976. Volcanic rocks of the Río Cauca valley, Colombia S.A. Thesis Degree of Master of Arts, Rice University, Houston. for mid-Tertiary magmatic rocks associated with a shallowing subduction zone and a 
673 thickening crust in the Central Andes $\left(28-33^{\circ} \mathrm{S}\right)$. In: Andean Magmatism and its 674 Tectonic Setting, Boulder, Colorado. Harmon, R.S., Rapela, C.W., eds. Spec. Pap. 675 Geol. Soc. Am. 265: 113 - 137.

676 Kellogg, J., Vega, V. 1995. Tectonic development of Panamá, Costa Rica, and the 677 Colombian Andes: Constraints from global positioning system geodetic studies and 678 gravity. Geological Society of America. Special Paper 295: 75 - 90.

679 Kerr, A.C. 2003. Oceanic Plateaus. In: Rudnick, R. (ed.) The Crust. Elsevier 680 Science: Oxford. Treatise on Geochemistry. 3: 537 - 565.

681 Kowallis, B.J., Heaton, J.S., Bringhurst, K., 1986. Fission-track dating of volcanically 682 derived sedimentary rocks. Geology 14, 19-22.

Labanieh, S., Chauvel, C., Germa, A., Quidelleur, X. 2012. Martinique: a clear case 684 for sediment melting and slab dehydration as a function of distance to the trench. Journal of Petrology. 53: $2441-2464$.

Leal-Mejía, H. 2011. Phanerozoic Gold Metallogeny in the Colombian Andes - A tectono-magmatic approach: Ph.D. thesis, Barcelona (Catalonia), Spain, University 688 of Barcelona, 1000p.

689 LeMaitre, R. W., Bateman, P., Dudek, A., Keller, J., Lameyre-LeBas, M. J., Sabine, P. A., Schmid, R., Sorensen, H., Streckeisen, A., Woolley, A. R. \& Zanettin, B., A. 1989. Classification of Igneous Rocks and Glossary of Terms Oxford: Blackwell. geochemistry, and Fluid Characterization of the Late Miocene Buriticá Gold Deposit, 694 Antioquia Department, Colombia. Economic Geology. 108: 1067 - 1097. 
695 Lonsdale, P. 2005, Creation of the Cocos and Nazca plates by fission of the 696 Farallón plate: Tectonophysics. 404 (3 - 4): 237 - 264

697

698

699

700

701

702

703

704

705

706

707

708

709

710

711

712

713

714

715

López, A., Sierra, G.M., Ramírez, S. 2006. Vulcanismo Neógeno en el suroccidente antioqueño y sus implicaciones tectónicas. Boletín Ciencias de la Tierra. 19: 27 - 41.

Mackenzie, W.S., Donaldson, C.H., Guilford, C. 1984. Atlas of igneous rocks and their textures. Longman Scientific and Technical, UK.

Mantilla, L.C., Bissig, T., Valencia, V., Hart, C.J.R., 2013. The magmatic history of the Vetas-California mining district, Santander Massif, Eastern Cordillera, Colombia. Journal of South American Earth Sciences 45, 235-249.

Marín-Cerón, M.I. 2007. Major, trace element and multi-isotopic systematics of SW Colombian volcanic arc, northern Andes: Contributions of slab fluid, mantle wedge and lower crust to the origin of Quaternary andesites. Doctoral thesis. Okayama University, Japan. 133 pp.

Marín-Cerón, M.I., Moriguti, T., Makishima, A., Nakamura, E. 2010. Slab decarbonation and $\mathrm{CO} 2$ recycling in the Southwestern Colombian volcanic arc. Geochimica et Cosmochimica Acta. 74: 1104 - 1121.

Marín-Cerón, M.I., Leal-Mejía, H., Bernet, M., Mesa-Garcia, J., 2019. Late Cenozoic to Modern-Day Volcanism in the Northern Andes: A Geochronological, Petrographical, and Geochemical Review. In Cediel, F., Shaw, R.P. (eds.) Geology and Tectonics of Northwestern South America, Frontiers in Earth Sciences, Springer Nature Switzerland., p. 603-648. 
Maro, G., Remesal, M.B. 2011. El vulcanismo de la Alta Sierra de Somún Curá: El

717 Cerro Corona, Provincia de Río Negro, Argentina. Abstract. XVIII Congreso 718 Geológico Argentino. Neuquén. 2 pp.

719 Marriner, G.F., Millward, D. 1984. Petrochemistry of Cretaceous to recent Vulcanism 720 in Colombia. Journal of Geological Society of London.141: 473 - 486.

McCourt, W.J., Aspden, J.A., Brook, M. 1984. New geological and geochronological data from the Colombian Andes: continental growth by multiple accretion. Journal of Geological Society, London. 141: $831-845$.

McDonough, W.F., Chauvel, C. 1991. Sample contamination explains the Pb isotopic composition of some Rurutu island and Sasha seamount basalts. Earth Planet. Sci. Lett. 105: $397-404$.

727 McDonough, W. F., Sun, S. S. 1995. Composition of the Earth. Chemical Geology. 120: $223-253$.

Mesa-Garcia, J. 2015. Combia Formation: a Miocene immature volcanic arc? EAFIT University Master thesis. 244 pp.

731 Nakamura, E., Campbell, I.H., Sun, S.S. 1985. The influence of subduction processes on the geochemistry of Japanese alkaline basalt. Nature. 316: 55 - 58.

Nelson, S.T., Montana, A. 1992. Sieve-textured plagioclase in volcanic rocks produced by rapid decompression. American Mineralogist. 77: $1242-1249$.

Nixon, G.T., Pearce, T. H. 1987. Laser-interferometry study of oscillatory zoning in plagioclase: The record of magma mixing and phenocryst recycling in calc- alkaline magma chambers, Iztaccihuatl Volcano, Mexico. Amer. Mineral. 72: 1144 - 1162. 
738 Ordoñez, O. 2002. Caracterizacao isotopica $\mathrm{Rb}-\mathrm{Sr} \mathrm{E} \mathrm{Sm}-\mathrm{Nd}$ dos principais 739 eventos magmáticos nos Andes Colombianos. Doctoral thesis. Brazilia University. $740165 \mathrm{pp}$.

741 Páez Acuna, L. 2012. Análisis estratigráfico y de proveniencia del Miembro Superior 742 de la Formación Amagá en los sectores de la Pintada y Valparaiso (cuenca Amagá, andes noroccidentales). Master thesis on Earth Sciences. EAFIT University.

744 Pardo, N., Cepeda, H., Jaramillo, J.M., 2005. The Paipa volcano, Eastern Cordillera of Colombia, South America: volcanic stratigraphy. Earth Sci. Res. J. 9, 3-18.

746 Pardo-Casas, F., Molnar, P. 1987. Relative motion of the Nazca (Farallón) and 747 South American plates since Late Cretaceous time. Tectonics 6 (3): 223 - 248.

748 Patiño, L. C, Carr, M., Feigenson, M. 2000. Local and regional variations in Central 749 American arc lavas controlled by variations in subducted sediment input. Contrib. Mineral Petrol. 138, 265-283.

751 Pedersen R., Furnes, H. 2001. Nd- and Pb-isotopic variations through the upper oceanic crust in DSDP/ODP Hole 504B, Costa Rica Rift. Earth and Planetary Sc. Lett. 189: $221-235$.

754 Pérez, A. L., 2005. Formación Combia: Litofacies y aproximación a su edad con base en estudios palinológicos, suroeste antioqueño. Undergraduate thesis. Medellín, EAFIT University.

757 Pérez, A.M., Marín-Cerón, M.I., Bernet, M., Sierra, G., Moreno, N. 2013. 758 Resultados preliminares de AFT en la Formación Amagá, Pozos el Cinco- 1B y 759 Venecia-1. XIV Congreso Colombiano de Geología Libro: XIV Congreso 760 Colombiano de Geología. Resúmenes. 
761 Perugini, D., Busa, T., Poli, G., Nazzareni, S. 2003. The role of chaotic dynamics and flow fields in the development of disequilibrium textures in volcanic rocks. Journal of Petrology. 44 (4): 733 - 756.

Pettijohn, F. J. 1975. Sedimentary rocks, third edition: New York, Harper \& Row. 628 pp.

Piedrahita, V.A., Bernet, M., Chadima, M., Sierra, G.M., Marín-Cerón, M.I., Toro, G.E., 2017. Detrital zircon fission-track thermochronology and magnetic fabric of the Amagá Formation (Colombia): Intracontinental deformation and exhumation events in the northwestern Andes. Sedimentray Geology, 356, 26-42.

Plank, T., Langmuir, C. 1998. The chemical composition of subducting sediment and its consequences for the crust and mantle, Chem. Geol. 145, 325 - 394.

Ramírez, D.A., López, A., Sierra, G.M., Toro, G.E. 2006. Edad y provenincia de las rocas volcánico sedimentarias de la Formación Combia en el suroccidente Antioqueño- Colombia. Boletin Ciencias de la Tierra. 19: 9 - 26.

Restrepo, J.J., Toussaint, J.F., González, H., 1981. Edades MioPliocenas del magmatismo asociado a la Formación Combia. Departamentos de Antioquia y Caldas, Colombia. Geología Norandina. 3: 2126.

Restrepo-Moreno, S.A., Foster, D.A., Stockli, D.F., Parra-Sánchez, L.N. 2009. Longterm erosion and exhumation of the „Altiplano Antioqueño", Northern Andes (Colombia) from apatite (U-Th)/He thermochronology. Earth and Planetary Science Letters. 278: $1-12$.

Restrepo-Moreno, S.A., Cardona, A., Jaramillo, C., Bayona, G., Montes, C., Farris, 
apatite and zircon low-temperature thermochronology: insights on the onset of collision and the morphotectonic history of the region. Abstract. GSA Denver Annual Meeting. Geological Society of America Abstracts with Programs. 42 (5): 521.

Rios, A.M., Sierra, M.I. 2004. La Formación Combia: Registro de la relación entre el volcanismo Neógeno y la sedimentación fluvial, sección Guineales - Bolombolo, suroeste antioqueño. Undergraduate thesis. EAFIT University. 122 pp.

Rodríguez-Vargas, A., Koester, E., Mallmann, G., Conceicao, R.V., Kawashita, K., Weber, M.B.I. 2005. Mantle diversity beneath the Colombian Andes, Northern Volcanic Zone: Constraints from Sr and Nd isotope. Lithos 82: $471-484$.

Rodríguez, G., Arango, M.I., Bermúdez, J.G. 2012. Batolito de Sabanalarga, plutonismo de arco en la zona de sutura entre las cortezas oceánica y continental de los Andes del Norte. Boletín Ciencias de la Tierra. (32): 81 - 98.

Rollinson, H.R. 1993. Using geochemical data: evaluation, presentation, interpretation. Longman group UK. 352 pp.

Saenz, E.A. 2003. Fission track thermochronology and denudational response to tectonics in the north of the Colombian Central Cordillera. Master thesis. Shimane Un Salters, V. \& Stracke, A. 2004. Composition of depleted mantle, Geochem, Geophys, Geosyst 5 (5): 27 pp.

Saunders, A.D., Norry M.J., Tarney, J. 1988. Origin of MORB and chemically depleted mantle reservoirs: trace element constraints. J. Petrology, Special Lithosphere Issue. 415 - 445.iversity. 131 pp.

Shibata T., Nakamura, E. 1997. Across-arc variations of isotope and trace element compositions from Quaternary basaltic volcanic rocks in northeastern Japan: 
implications for interaction between subducted oceanic slab and mantle wedge. J. Geophys. Res. 102: $8051-8064$.

Sierra, G. 1994. Structural and sedimentary evolution of the Irra Basin, northern Colombian Andes. Master thesis, Department of Geological Science, State University of New York, Binghamton, NY. 102 pp.

Sierra, G.M., Marín Cerón, M.I., 2011. Petroleum Geology of Colombia. Amagá, Cauca and Patía Basins. Agencia Nacional de Hidrocarburos. 104 pp.

Silva, J.C., Sierra, G.M., Correa, L.G. 2008. Tectonic and climate driven fluctuations in the stratigraphic base level of a Cenozoic continental coal basin, northwestern Andes. Journal of South American Earth Sciences. 26: 369 - 382.

Singer, B.S., Dungan, M.A., Layne, G.D. 1995. Textures and Sr, Ba, Mg, Fe, K, and Ti compositional profiles in volcanic plagioclase: Clues to the dynamics of calcalkaline magma chambers. American Mineralogist. 80: 776 - 798.

Stern, C.R. 2004. Active Andean volcanism: its geologic and tectonic setting. Andean Geology. 31 (2): $161-206$.

Stern, C.R., Moreno, H., López-Escobar, L., Clavero, J.E., Lara, L.E., Naranjo, J.A., Parada, M.A., Skewes, M.A. 2007. Chilean volcanoes. In: The Geology of Chile. Moreno, T., Gibbons, W. (eds) The Geological Society, UK. 147 - 178.

Streckeisen, A. 1976. To Each Plutonic Rock its Proper Name. Earth Science Review. 12: 1-33.

Sun, S.-s. and McDonough, W.F.. 1989. Chemical and isotopic systematics of oceanic basalts: implications for mantle composition and processes. In: 4.D. 
829 Saunders and M.J. Norry (Editors). Magmatism in the Ocean Basins. Geological 830 Society. London. pp. 3 13-345.

831 Taboada, A., Rivera, Luís A., Fuenzalida, A., Cisternas, A., Philip, Hervé, Bijwaard, 832 H., Olaya, J., and Rivera, C., 2000. Geodynamics of the northern Andes: 833 Subductions and intracontinental deformation (Colombia). Tectonics. 19 (5): 787 834813.

835 Tamura, Y., Nakamura, E. 1996. The arc lavas of the Shirahama Group Japan: Sr 836 and $\mathrm{Nd}$ isotopic data indicate mantle-derived bimodal magmatism. Journal of 837 petrology. $37(6): 1307-1319$.

838 Tassinari, C.C.G., Díaz, F., Buena, J. 2008. Age and sources of gold mineralization 839 in the Marmato mining district, NW Colombia: A Miocene - Pliocene epizonal 840 gold deposit. Ore Geology Reviews. 33: 505 - 518

841 Tatsumi, Y. 2005. The subduction factory: how it operates in the evolving earth. GSA 842 today. $15(7): 4-10$.

843 Tatsumi, Y., Stern, R.J. 2006. Manufacturing continental crust in the subduction 844 factory. Oceanography. 19 (4): $104-112$.

845 Tatsumi, Y., Takahashi, T. 2006. Operation of the subduction factory and 846 production of andesite. Journal of Mineralogical and Petrographical Sciences. 101: $847 \quad 145-153$.

848 Thorpe, R.S. 1984. The tectonic setting of active Andean volcanism. In Andean 849 magmatism: Chemical and Isotopic Constraints (Harmon, R.S.; Barreiro, B.A.; 850 editors). Shiva Geological Series, Shiva Publications, Nantwich, U.K. 4 - 8. 
851 Thorpe, R.S., Francis, P.W. 1979. Variations in Andean andesite composition and 852 their petrogenetic significance. Tectonophysics. 57: $53-70$.

853 Thorpe, R. S., Francis, P. W, Hammill, M., Baker, M.C.W., 1982. The Andes. 854 Andesites. Ed Thorpe, R.S. 187 - 205.

855 Toro, G; Restrepo, JJ; Poupeau, G; Saenz, E y Azdimousa, A. 1999. Datación por 856 trazas de fisión de circones rosados asociados a la secuencia volcano 857 sedimentaria de Irra (Caldas). Boletín de Ciencias de la Tierra. 13: 28 - 34.

858 Trenkamp, R., Kellogg, J.N., Freymueller, J.T., Mora, H.P., 2002. Wide plate margin 859 deformation, southern Central America and northwestern South America, CASA 860 GPS observations. Journal of South American Earth Sciences. 15: 157 - 171.

861 Uribe - Mogollón, C.A., 2013. Hydrothermal evolution of the Titiribí mining district. 862 Undergraduate thesis. EAFIT University. 127 pp.

863 van der Hammen, T., 1960. Estratigrafía del Terciario y Maastrichtiano continentales 864 y tectogénesis de los Andes Colombianos, Informe No. 1279. Servicio Geológico 865 Nacional, Bogotá. 128 pp.

866 Vargas, C., Mann, P.2013. Tearing and breaking off of subducted slabs as the result 867 of collision of the Panama arc-indenter with northwestern South America. Bull. 868 Seismol. Soc. Am. 103:2025-2046.

869 Vermeesch, P. 2009. RadialPlotter: A Java application for fission track, 870 luminescence and other radial plots. Radiation Measurements. 44: 409 - 410. 
871 Walker, G.P.L., Wilson, C.J.N., Froggat, P.C. 1991. An ignimbrite veneer deposits; 872 the trail marker of a pyroclastic flow. Journal of Volcanology and Geothermal 873 Research. 9: $409-421$.

874 Weber, M.B.I., Tarney, J., Kempton, P.D. and Kent, R. W., 2002, Crustal make-up of 875 the northern Andes: evidence based on deep crustal xenolith suites, Mercaderes, 876 SW Colombia. Tectonophysics. 345: $49-82$.

877 White, W.M. 2013. Geochemistry (1st ed). Hoboke, NJ, Wiley-Blackwell. 660 pp.

878 White, W.M., Dupre, B., Vidal, P. 1985. Isotope and trace element geochemistry of 879 sediments from the Barbados Ridge - Demerara Plain region, Atlantic Ocean. 880 Geochim. Cosmochim. Acta. 49: 1875 - 1886.

881 Wilson, M. 1989. Igneous petrogenesis: a global tectonic approach. London, UK, 882 Chapman \& Hall. 466 pp.

Winter, J.D. 2001. Introduction to igneous and metamorphic petrology. Upper Saddle 884 River, New Jersey, Prentice Hall. 796 pp.

Wörner, G.; Davidson, J.; Moorbath, S.; Turner, T.L.; McMillan, N.; Nye, C.; López886 Escobar, L.; Moreno, H. 1988. The Nevados de Payachata Volcanic Region $18^{\circ} \mathrm{S} / 69^{\circ} \mathrm{W}$, Northern Chile. I. Geological, geochemical and isotopic observations. Bulletin of Volcanology. 30: 287 - 303.

\section{Figure captions}

892 Fig. 1 Overview map of the Colombia Andes, showing the subduction of the Nazca and Caribbean plates beneath the South American plate. Also shown are the 
894 Western, Central and Eastern Cordilleras and areas of Pliocene to present volcanic activity, as well as the location of the study area (map from GeoMapApp, http://www.geomapapp.org/).

897 Fig. 2 Geological map of the Amagá basin with the locations of the Cerro Amarillo 898 (CA), Anzá-Bolombolo ( $A B)$ and La Metida Creek (MC) sections (modified after 899 Sierra and Marín-Cerón, 2011).

900 Fig. 3 Cerro Amarillo stratigraphic of the eastern Amagá basin.

901 Fig. 4 Anzá Bolombolo stratigraphic section of the western Amagá basin.

902 Fig. 5 La Mertida Creek stratigraphic section of the western Amagá basin.

903 Fig. 6 Combined fission-track data radial plots of A) apatite fission-track data and B) 904 zircon fission track data with central ages.

905 Fig. 7 A) Streckeisen (1976) volcanic rock classification diagram. Both the Anzá906 Bolombolo and Cerro Amarillo samples plot in the andesite, basalt field. B) 907 Pyroclastic rock classification diagram of Pettijohn (1975), in which almost all La 908 Metida Creek and Anzó-Bolombolo pyroclastic rock samples plot in the crystal tuff 909 field.

Fig. 8 A) AFM diagram plot (Irvine and Baragar, 1971) for volcanic rocks from the Cerro Amarillo and Anzá- Bolombolo sections. For comparison, data of Marriner and Millward (1984), Ordoñez (2001) and Leal-Mejía (2011) from the Combia Formation are also shown. B) Total alkalis versus silica (TAS) diagram of volcanic rocks from the Cerro Amarillo and Anzá Bolombolo sections; boundaries in the total alkalis are from LeMaitre et al. (1989) for rock classification and Irvine and Baragar (1971) for magma series classification (red solid line). For comparison, data of Marriner and Millward (1984), Ordoñez (2001) and Leal-Mejía (2011) are shown.

918 Fig. 9 A) Primordial mantle (McDonough and Sun, 1995) normalized trace element 919 spider diagrams of volcanic rocks from the Cerro Amarillo and Anzá-Bolombolo 920 sections. B) Chondrite (Evensen et al., 1978) normalized Rare Earth Element (REE) patterns of the volcanic rocks from the Cerro Amarillo section. C) For comparison trace element patterns of published data by Leall-Mejia (2011) from Combia Formation and hypabyssal porphyritic intrusions in the study area, as summarized in 
924 Marín-Cerón et al. (2019). Trace element data normalized after Wood et al. (1979).

925 D) For comparison, published REE data of Leal-Mejía (2011) normalized after Sun

926 and McDonough (1989) for hypabyssal porphyritic intrusions, Combia Formation volcanic rocks and recent to present volcanism in the Central Cordillera, as summarized in Marín-Cerón et al. (2019). E) The La/Sm versus Ba/Th plot indicates that the Cerro Amarillo volcanic rocks were more derived from magma related to slab dehydration, whereas the Anzá-Bolombolo samples trend more towards sediment melting derived magma.

Fig. 10 Comparison between trace elements and isotopic systematics: A) $\mathrm{Sr} / \mathrm{Th}$ versus ${ }^{87} \mathrm{Sr} /{ }^{86} \mathrm{Sr}$, and $\mathrm{B}$ ) $\mathrm{Ba} / \mathrm{Th}$ versus ${ }^{143} \mathrm{Nd} /{ }^{144} \mathrm{Nd}$, for volcanic rocks of the $\mathrm{CA}$ section (blue circles) and the $A B$ section (red circles). The dashed line represents altered oceanic crust values (AOC) (after Barret, 1983). Both diagrams show that addition of fluids to the magma affected the geochemistry to the analyzed rocks and that the slab dehydration effects are more pronounced in the eastern than the western Amagá basin. C) Nd vs. Sr isotope ratio plot, showing the fields for the Northern Volcanic Zone (NVZ), Central Volcanic Zone (CVZ) and Southern Volcanic Zone (SVZ) as well as typical MORB composition, based on data from James et al. (1976); Hawkesworth et al. (1979); James (1982); Harmon et al. (1984); Frey et al. (1984); Thorpe (1984); Hickey et al. (1986); Hildreth and Moorbath (1988); Wörner et al. (1988); Walker et al. (1991); de Silva (1991); Kay et al. (1991); Davidson and de Silva (1992). Winter (2001); Marín-Cerón (2007), as summarized by and plot modified from Marín-Cerón et al. (2019). The data of our study are shown for the Cerro Amarillo section (yellow circles) and the Anzá-Bolombolo section (red circles), plotted over the NVZ field.

Fig. 11 Lead isotopic systematics of the Combia Formation shown for the Cerro Amarillo section (yellow circles) and the Anzá-Bolombolo section (red circles). A) Plots of ${ }^{208} \mathrm{~Pb} /{ }^{204} \mathrm{~Pb}$ vs ${ }^{206} \mathrm{~Pb} /{ }^{204} \mathrm{~Pb}$ for the Andean volcanic zones (Northern Volcanic Zone - NVZ; Central Volcanic Zone - CVZ; and Southern Volcanic Zone - SVZ) and the pre-Andean basement (plot modified from data compilation plot of Marín-Cerón (2019). Pacific sediments (Dasch, 1981; White et al., 1985); Paleozoic basement (Chiaradia and Fontboté, 2002); metalliferous sediments from DSDP leg 92 (Barret et al., 1987). B) Zoom on the ${ }^{208} \mathrm{~Pb} /{ }^{204} \mathrm{~Pb}$ vs ${ }^{206} \mathrm{~Pb} /{ }^{204} \mathrm{~Pb}$ diagram. Squares represent possible end-members and the respective trends of the interaction between each of 
957 the components involved during magma formation. AOC: altered oceanic crust; HS: 958 hemipelagic sediments; CS: carbonaceous sediments; LCC: lower continental crust. 959 The solid blue line represents the linear trend of the samples suggesting bimodal 960 mixing between primary magma (yellow star) and LCC. This plot is based on the 961 compilation of Marín-Cerón et al. (2019); Cretaceous Domain (Kerr, 2003); Lower 962 crust xenotiths (Weber et al., 2002); and ACC from Hole 504 (Pedersen and Furnes, 963 2001); NVZ data from Marín-Cerón (2007). The data from our study study are shown 964 for the Cerro Amarillo section (yellow circles) and the Anzá-Bolombolo section (red circles) and the plotted over the Northern Volcanic Zone field.

966 Fig. 12 Schematic diagram for magma source genesis of Combia Formation 967 volcanism. AOC: altered oceanic crust; HS: hemipelagic sediments; CS: carbonaceous sediments; AFC: assimilation fraction crystallization processes (DePaolo, 1981); MASH: melting, assimilation, storage, and homogenization processes (Hildreth \& Moorbath, 1988); LCC: lower continental crust; UCC: upper continental crust. Illustration based on model proposed for southwestern Colombian volcanism (Marín-Cerón, 2007) and is compatible with models presented in Marín973 Cerón et al. (2019).

Tables

Table 1 Apatite fission-track data of the Combia Formation

Table 2 Zircon fission-track data of the La Metida Creek Formation

979 Table 3 Petrographic modal analyses

980 Table 4 Major elements (wt\%) of the Cerro Amarillo and Anzá-Bolombolo section 981 samples

982 Table 5 Trace elements (ppm) of volcanic rock samples of the Cerro Amarillo and 983 Anzá-Bolombolo sections

984 Table 6 Isotopic compositions of volcanic rocks from the Cerro Amarillo and Anzá985 Bolombolo sections. 
986 Table 7 Estimated isotopic compositions and parameters for end-member involved in 987 magma genesis 
Table 1 Apatite fission-track data of the Combia Formation

\begin{tabular}{|c|c|c|c|c|c|c|c|c|c|c|c|c|}
\hline $\begin{array}{l}\text { Sample } \\
\text { number }\end{array}$ & Lithology & $\begin{array}{c}\text { Number } \\
\text { of } \\
\text { grains }\end{array}$ & $\begin{array}{l}\text { Single grain } \\
\text { age range } \\
\text { (Ma) }\end{array}$ & $\begin{array}{c}\text { RhoS } \\
\left(\times 10^{5} \mathrm{t} / \mathrm{cm}^{2}\right)\end{array}$ & Ns & $\begin{array}{c}\text { Rhol } \\
\left(\times 10^{5} \mathrm{t} / \mathrm{cm}^{2}\right)\end{array}$ & $\mathrm{Ni}$ & $\begin{array}{c}\text { RhoD } \\
\left(\times 10^{5} \mathrm{t} / \mathrm{cm}^{2}\right)\end{array}$ & $\mathrm{P}\left(\chi^{2}\right)(\%)$ & $\begin{array}{c}\text { Age } \\
\text { dispersion } \\
(\%) \\
\end{array}$ & $\begin{array}{c}\text { Central } \\
\text { age* (Ma) } \\
\pm 2 \mathrm{SE} \\
\end{array}$ & $\begin{array}{c}\mathrm{U}(\mathrm{ppm}) \\
\pm 2 \mathrm{SE}\end{array}$ \\
\hline \multicolumn{13}{|c|}{$A B$ section } \\
\hline $\mathrm{JJ} 13$ & $\begin{array}{l}\text { Pyroclastic } \\
\text { agglomerate }\end{array}$ & 60 & $2.8-36.9$ & 0.28 & 67 & 4.88 & 1183 & 9.72 & 44.9 & 2.7 & $7.9 \pm 2.1$ & $6 \pm 0$ \\
\hline JJ22 & Tuff & 35 & $3.2-38.5$ & 0.29 & 35 & 4.96 & 592 & 9.72 & 36.3 & 24.0 & $8.4 \pm 3.1$ & $7 \pm 1$ \\
\hline \multicolumn{13}{|c|}{ MC section } \\
\hline JJ17 & Lapilli - tuff & 60 & $3.6-71.5$ & 0.26 & 36 & 4.57 & 624 & 9.72 & 7.3 & 50.8 & $8.3 \pm 3.1$ & $6 \pm 0$ \\
\hline JJ14 & Tuff & 33 & $4.9-374.9$ & 0.29 & 18 & 3.34 & 209 & 9.72 & 0.0 & 141.1 & $15.9 \pm 11.1$ & $4 \pm 1$ \\
\hline JJ21 & Tuff & 51 & $3.5-74.2$ & 0.17 & 19 & 4.56 & 517 & 9.72 & 66.9 & 2.0 & $5.1 \pm 2.5$ & $6 \pm 1$ \\
\hline $\mathrm{JJ} 18$ & $\begin{array}{l}\text { Volcaniclastic } \\
\text { sandstone }\end{array}$ & 16 & $4.7-48.9$ & 0.23 & 7 & 4.59 & 139 & 9.72 & 0.9 & 155.4 & $7.3 \pm 9.4$ & $6 \pm 1$ \\
\hline JJ19 & Tuff & 20 & $6.6-138.7$ & 0.24 & 10 & 3.23 & 133 & 9.72 & 45.7 & 2.1 & $10.5 \pm 7.3$ & $4 \pm 1$ \\
\hline $\mathrm{JJ} 20$ & Lapilli tuff breccia & 27 & $4.9-138.5$ & 0.50 & 28 & 5.68 & 317 & 9.72 & 6.9 & 57.1 & $15.8 \pm 9.2$ & $9 \pm 1$ \\
\hline combined & & 302 & $2.8-374.9$ & & & & & 9.72 & 0.0 & 48.6 & $8.6 \pm 1.4$ & $6 \pm 0$ \\
\hline
\end{tabular}

Note - RhoS: spontaneous track density. Rhol: induced track density; $\mathrm{P}\left(\chi^{2}\right): \mathrm{Chi}^{2}$ probability. Fission-track ages were calculated using a Zeta value of $288.36 \pm 7.90$. AFT data calculated with Binomfit of Brandon (see Ehlers et al., 2005). 
Table 2 Zircon fission-track data of the La Metida Creek Formation

\begin{tabular}{|c|c|c|c|c|c|c|c|c|c|c|c|c|}
\hline $\begin{array}{l}\text { Sample } \\
\text { number }\end{array}$ & Lithology & $\begin{array}{c}\text { Number } \\
\text { of } \\
\text { grains }\end{array}$ & $\begin{array}{c}\text { Single grain } \\
\text { age range } \\
\text { (Ma) }\end{array}$ & $\begin{array}{c}\text { RhoS } \\
\left(\times 10^{5} \mathrm{t} / \mathrm{cm}^{2}\right)\end{array}$ & Ns & $\begin{array}{c}\text { Rhol } \\
\left(\times 10^{5} \mathrm{t} / \mathrm{cm}^{2}\right)\end{array}$ & $\mathrm{Ni}$ & $\begin{array}{c}\text { RhoD } \\
\left(x 10^{5} \mathrm{t} / \mathrm{cm}^{2}\right)\end{array}$ & $\begin{array}{l}\mathrm{P}\left(\chi^{2}\right) \\
(\%)\end{array}$ & $\begin{array}{c}\text { Age } \\
\text { dispersion } \\
\text { (\%) }\end{array}$ & $\begin{array}{l}\text { Central } \\
\text { age* (Ma) } \\
\pm 2 \mathrm{SE}\end{array}$ & $\begin{array}{c}\mathrm{U}(\mathrm{ppm}) \\
\pm 2 \mathrm{SE}\end{array}$ \\
\hline JJ1 & $\begin{array}{l}\text { Lapilli tuff } \\
\text { breccia }\end{array}$ & 30 & $1.0-14.3$ & 4.65 & 175 & 17.6 & 662 & 2.71 & 24.4 & 24.2 & $6.7 \pm 1.5$ & $258 \pm 21$ \\
\hline JJ8 & Tuff & 12 & $2.1-19.4$ & 5.89 & 58 & 24.1 & 237 & 2.67 & 3.3 & 44.3 & $6.2 \pm 2.6$ & $359 \pm 47$ \\
\hline JJ3 & Tuff & 25 & $4.0-19.5$ & 10.6 & 383 & 27.5 & 993 & 2.71 & 47.5 & 6.6 & $10.0 \pm 1.7$ & $405 \pm 28$ \\
\hline פנJ & Tuff & 28 & $0.9-25.5$ & 13.2 & 570 & 33.1 & 1432 & 2.67 & 0.0 & 35.3 & $10.1 \pm 2.1$ & $493 \pm 29$ \\
\hline JJ10 & Tuff & 22 & $5.0-20.0$ & 10.5 & 363 & 28.6 & 989 & 2.66 & 68.0 & 0.6 & $9.3 \pm 1.5$ & $427 \pm 29$ \\
\hline JJ4 & Tuff & 31 & $2.9-25.8$ & 17.7 & 585 & 38.8 & 1280 & 2.70 & 0.3 & 24.1 & $11.2 \pm 2.0$ & $572 \pm 36$ \\
\hline JJ6 & $\begin{array}{c}\text { Volcaniclastic } \\
\text { sandstone }\end{array}$ & 51 & $2.9-46.7$ & 10.6 & 909 & 22.1 & 1844 & 2.69 & 0.0 & 44.1 & $12.7 \pm 2.4$ & $327 \pm 17$ \\
\hline JJ5 & Tuff & 31 & $2.6-14.8$ & 14.1 & 515 & 3.85 & 1405 & 2.69 & 73.1 & 6.5 & $9.4 \pm 1.4$ & $569 \pm 14$ \\
\hline JJ11 & $\begin{array}{l}\text { Lapilli tuff } \\
\text { breccia }\end{array}$ & 48 & $1.3-16.1$ & 6.27 & 362 & 2.63 & 1517 & 2.65 & 14.2 & 19.6 & $6.1 \pm 1.1$ & $394 \pm 22$ \\
\hline JJ7 & $\begin{array}{l}\text { Lapilli tuff } \\
\text { breccia }\end{array}$ & 68 & $4.3-14.8$ & 9.00 & 824 & 29.5 & 2705 & 2.68 & 94.0 & 0.7 & $7.8 \pm 1.1$ & $439 \pm 20$ \\
\hline Combined & & 346 & $0.9-46.7$ & 10.2 & 4744 & 28.5 & 13206 & 2.68 & 0.0 & 33.9 & $9.1 \pm 1.1$ & $418 \pm 14$ \\
\hline
\end{tabular}

Note - RhoS: spontaneous track density. Rhol: induced track density; $\mathrm{P}\left(\chi^{2}\right): \mathrm{Chi}^{2}$ probability. Fission-track ages were calculated using a Zeta value of $191.6 \pm 10.25$. ZFT data calculated with Binomfit of Brandon (see Ehlers et al., 2005). 
Table 3 Petrographic modal analyses

\begin{tabular}{|c|c|c|c|c|c|c|c|c|c|c|}
\hline CA section & CA - 1 & $C A-2$ & $C A-7$ & $C A-13$ & CA - 14 & CA - 18 & $C A-22$ & & & \\
\hline Plagioclase & 48.61 & 19.1 & 36.2 & 9.25 & 32.1 & 89.7 & 31.2 & & & \\
\hline Hypersthene & --- & 42.2 & 23.5 & 51.2 & 47.2 & 10.3 & 21.8 & & & \\
\hline Augite & 13.19 & 4.7 & 3.2 & 9 & 9.89 & --- & 9.5 & & & \\
\hline Hornblende & 3.47 & 0.6 & --- & --- & --- & --- & 5.4 & & & \\
\hline Calcite & 9.03 & 1.3 & --- & --- & 7.58 & --- & 5.01 & & & \\
\hline Olivine & 5.21 & --- & --- & --- & --- & --- & 8 & & & \\
\hline Biotite & --- & 0.5 & 0.32 & 1 & 3.23 & --- & 1.6 & & & \\
\hline Sericite & --- & --- & 3.5 & --- & --- & --- & --- & & & \\
\hline Rock fragments & 19.8 & 19.4 & 28.6 & 29.55 & --- & --- & 17.49 & & & \\
\hline Oxides & --- & 8.8 & 4.8 & --- & --- & --- & --- & & & \\
\hline Opaque minerals & 0.69 & 3.4 & --- & --- & --- & --- & --- & & & \\
\hline Total & 100 & 100 & 100.12 & 100 & 100 & 100 & 100 & & & \\
\hline AB section & $A B-2$ & $A B-6$ & $A B-7$ & & & & & & & \\
\hline Plagioclase & 57.14 & 69.13 & 52.22 & & & & & & & \\
\hline Pyroxene & 42.86 & 12.01 & 29.1 & & & & & & & \\
\hline Spherulites & --- & 9.86 & 18.68 & & & & & & & \\
\hline Olivine & --- & 9 & --- & & & & & & & \\
\hline Total & 100 & 100 & 100 & & & & & & & \\
\hline MC section & QML - 1 & $\mathrm{QML}-6$ & QML - 7 & $\mathrm{QML}-9$ & QML - 10 & QML - 14 & QML - 18 & QML - 22 & QML - 28 & QML - 31 \\
\hline Plagioclase & 71.22 & 61.4 & 55 & 40 & 57.14 & 85 & 57.5 & 62.5 & 60 & 77.14 \\
\hline Pyroxene & --- & 10.53 & 15 & 20 & 22.85 & 7.6 & 25 & 25 & 25 & 14.29 \\
\hline Hornblende & 5.91 & 5.26 & 5 & --- & --- & 2.4 & --- & --- & --- & --- \\
\hline Biotite & 0.33 & --- & --- & --- & --- & --- & --- & --- & --- & --- \\
\hline Oxides & 2.13 & --- & --- & 5.71 & 5.72 & 5 & --- & 12.5 & 15 & 8.57 \\
\hline Rock fragments & 16.48 & 15.79 & --- & 8.57 & --- & --- & --- & --- & --- & --- \\
\hline Opaque minerals & 3.94 & 7.02 & 25 & 25.72 & 14.29 & --- & --- & --- & --- & --- \\
\hline Spherulites & --- & --- & --- & --- & --- & --- & 17.5 & --- & --- & --- \\
\hline Total & 100.01 & 100 & 100 & 100 & 100 & 100 & 100 & 100 & 100 & 100 \\
\hline
\end{tabular}


Table 4 Major elements (wt \%) of the Cerro Amarillo and Anzó - Bolombolo section samples

\begin{tabular}{|c|c|c|c|c|c|c|c|c|c|c|c|c|c|c|c|c|}
\hline $\begin{array}{l}\text { Oxides } \\
\text { (wt \%) }\end{array}$ & JJ1 - 3 & JJ1 - 6 & JJ1 - 9 & JJ1 - 13 & JJ1 - 17 & JJ1 - 18 & JJ1 - 20 & JJ1 - 23 & JJ3 - 2 & JJ3 - 5 & JJ3 - 6 & JJ3 - 9 & JJ4 - 2 & JJ4 - 3 & $\begin{array}{c}\text { JJ2-1- } \\
10\end{array}$ & $\begin{array}{c}\text { JJ2-1- } \\
14\end{array}$ \\
\hline $\mathrm{SiO}_{2}$ & 53.20 & 52.68 & 52.56 & 52.62 & 52.55 & 52.10 & 52.49 & 52.64 & 52.09 & 51.19 & 52.07 & 52.22 & 51.78 & 52.34 & 55.45 & 55.78 \\
\hline $\mathrm{Al}_{2} \mathrm{O}_{3}$ & 14.80 & 14.70 & 14.82 & 14.71 & 14.66 & 14.61 & 14.59 & 14.87 & 18.30 & 15.29 & 15.05 & 15.22 & 17.49 & 17.66 & 19.02 & 18.93 \\
\hline $\mathrm{Fe}_{2} \mathrm{O}_{3} \mathrm{t}$ & 12.03 & 11.77 & 12.13 & 12.82 & 12.67 & 12.55 & 12.93 & 12.75 & 10.40 & 13.44 & 13.48 & 13.63 & 10.49 & 10.23 & 5.01 & 5.53 \\
\hline MnO & 0.19 & 0.17 & 0.17 & 0.19 & 0.19 & 0.18 & 0.19 & 0.18 & 0.18 & 0.21 & 0.21 & 0.21 & 0.17 & 0.17 & 0.09 & 0.09 \\
\hline MgO & 3.56 & 3.51 & 3.32 & 3.48 & 3.43 & 3.32 & 3.49 & 3.30 & 2.99 & 3.44 & 3.50 & 3.46 & 3.48 & 3.05 & 1.05 & 1.12 \\
\hline $\mathrm{CaO}$ & 7.68 & 7.82 & 7.56 & 7.57 & 7.58 & 7.47 & 7.36 & 7.50 & 9.33 & 8.28 & 8.35 & 8.24 & 8.80 & 8.84 & 4.51 & 5.28 \\
\hline $\mathrm{Na}_{2} \mathrm{O}$ & 2.95 & 2.74 & 2.63 & 2.60 & 2.69 & 2.70 & 2.76 & 2.80 & 2.66 & 2.76 & 2.89 & 2.80 & 2.94 & 2.98 & 3.58 & 3.73 \\
\hline $\mathrm{K}_{2} \mathrm{O}$ & 1.89 & 1.75 & 1.94 & 1.88 & 1.98 & 1.84 & 1.79 & 1.82 & 1.20 & 1.40 & 1.25 & 1.45 & 1.47 & 1.48 & 3.58 & 4.60 \\
\hline $\mathrm{TiO}_{2}$ & 1.31 & 1.30 & 1.38 & 1.39 & 1.38 & 1.38 & 1.38 & 1.38 & 0.86 & 1.03 & 1.06 & 1.06 & 0.96 & 0.99 & 5.10 & 0.52 \\
\hline $\mathrm{P}_{2} \mathrm{O}_{5}$ & 0.48 & 0.48 & & 0.50 & 0.50 & 0.51 & 0.52 & 0.51 & 0.28 & 0.39 & 0.39 & 0.39 & 0.44 & 0.46 & 0.47 & 0.49 \\
\hline LOI & 1.48 & 2.75 & 2.60 & 2.19 & 1.77 & 1.98 & 1.47 & 1.74 & 1.12 & 1.63 & 1.63 & 1.65 & 2.08 & 2.31 & 5.18 & 2.70 \\
\hline SUM & 99.67 & 99.11 & 99.95 & 99.4 & 98.64 & 98.97 & 99.49 & 99.41 & 99.06 & 99.88 & 100.33 & 100.1 & 100.51 & 98.45 & 98.77 & 99.67 \\
\hline
\end{tabular}


Table 5 Trace elements (ppm) of volcanic rock samples of the Cerro Amarillo and Anzó Bolombolo sections.

\begin{tabular}{|c|c|c|c|c|c|c|c|c|c|c|c|c|c|c|c|c|}
\hline & JJ1-3 & JJ1-6 & JJ1-9 & JJ1-13 & JJ1-17 & JJ1-18 & JJ1-20 & JJ1-23 & JJ3-2 & JJ3-5 & JJ3-6 & JJ3-9 & JJ4-2 & JJ4-3 & JJ2-1-10 & J22-1-14 \\
\hline Li & 8.52 & 8.33 & 7.58 & 8.46 & 8.73 & 9.75 & 8.71 & 10.4 & 8.98 & 8.76 & 7.64 & 9.39 & 8.07 & 8.38 & 13.6 & 15.5 \\
\hline Sc & 31 & 30.7 & 30.2 & 30.5 & 30.1 & 29.5 & 30.1 & 30.4 & 27.4 & 33 & 32.8 & 33.1 & 24 & 24.8 & 8 & 8.75 \\
\hline $\mathrm{Ti}$ & 7840 & 7760 & 8270 & 8340 & 8210 & 8110 & 8250 & 8240 & 5070 & 6170 & 6160 & 6200 & 5690 & 5900 & 2710 & 3020 \\
\hline v & 343 & 340 & 367 & 369 & 361 & 365 & 366 & 367 & 296 & 331 & 338 & 337 & 268 & 278 & 96.9 & 100 \\
\hline $\mathrm{Cr}$ & 12.7 & 11.6 & 13.5 & 13.1 & 13.2 & 13.5 & 13.5 & 13.3 & 10.9 & 15.7 & 16.5 & 17.2 & 31.4 & 32.6 & 1.4 & 1.02 \\
\hline Co & 33.1 & 30.7 & 33.7 & 34.5 & 34.9 & 35.2 & 34.7 & 35.5 & 25.4 & 34.7 & 34.2 & 35.6 & 28 & 26.3 & 9.58 & 11.8 \\
\hline $\mathrm{Ni}$ & 14.9 & 13 & 16 & 16.5 & 17.1 & 17.3 & 16.6 & 18 & 7.18 & 9.99 & 9.79 & 10.3 & 20.2 & 17.7 & 2.35 & 2.63 \\
\hline $\mathrm{Cu}$ & 224 & 203 & 227 & 220 & 223 & 240 & 226 & 238 & 127 & 184 & 169 & 179 & 191 & 187 & 117 & 143 \\
\hline Zn & 107 & 136 & 116 & 120 & 114 & 116 & 115 & 116 & 86.6 & 111 & 112 & 114 & 100 & 96.9 & 70.3 & 74.2 \\
\hline As & 25.1 & 6.22 & 6.78 & 3.1 & 7.12 & 10.5 & 6.82 & 8.08 & 3.19 & 4.37 & 4.68 & 4.61 & 5.37 & 5.99 & 4.38 & 3.9 \\
\hline $\mathbf{R b}$ & 43.9 & 42.3 & 49.9 & 51.4 & 49.2 & 51.5 & 49.3 & 50.1 & 25.8 & 32.9 & 34.7 & 34 & 37.2 & 38.3 & 169 & 130 \\
\hline $\mathrm{Sr}$ & 475 & 478 & 470 & 457 & 459 & 461 & 453 & 457 & 558 & 497 & 457 & 473 & 483 & 489 & 1870 & 1170 \\
\hline $\mathbf{Y}$ & 26 & 26 & 28 & 27.5 & 27.2 & 27.6 & 27.3 & 27.4 & 18.9 & 23.3 & 23.5 & 24 & 21 & 22.2 & 15.5 & 17 \\
\hline $\mathrm{Zr}$ & 110 & 108 & 116 & 115 & 114 & 116 & 114 & 115 & 55.7 & 75 & 76.2 & 77 & 65.7 & 68.5 & 106 & 118 \\
\hline Nb & 5.97 & 5.83 & 6.18 & 6.25 & 6.11 & 6.26 & 6.19 & 6.16 & 2.63 & 3.03 & 3.07 & 3.06 & 3.05 & 3.16 & 4.86 & 5.54 \\
\hline
\end{tabular}




\begin{tabular}{|c|c|c|c|c|c|c|c|c|c|c|c|c|c|c|c|c|}
\hline & JJ1-3 & JJ1-6 & JJ1-9 & JJ1-13 & JJ1-17 & JJ1-18 & JJ1-20 & JJ1-23 & JJ3-2 & JJ3-5 & JJ3-6 & JJ3-9 & JJ4-2 & JJ4-3 & JJ2-1-10 & J22-1-14 \\
\hline $\mathrm{Cd}$ & 0.0498 & 0.108 & 0.0574 & 0.0541 & 0.0487 & 0.0538 & 0.055 & 0.058 & 0.0441 & 0.0513 & 0.0469 & 0.0488 & 0.045 & 0.0461 & 0.0391 & 0.049 \\
\hline Cs & 1.51 & 1.73 & 1.86 & 1.97 & 1.76 & 1.96 & 1.84 & 2 & 0.884 & 1.12 & 1.23 & 1.19 & 1.35 & 1.59 & 3 & 1.11 \\
\hline $\mathrm{Ba}$ & 967 & 948 & 1030 & 990 & 1030 & 1010 & 1000 & 1010 & 607 & 842 & 823 & 847 & 717 & 742 & 1350 & 1250 \\
\hline La & 10.5 & 10.5 & 11.2 & 11.2 & 11.1 & 11.3 & 11.2 & 11.2 & 5.7 & 7.46 & 7.54 & 7.62 & 7.14 & 7.39 & 19.7 & 21.4 \\
\hline $\mathrm{Ce}$ & 22.7 & 22.6 & 23.9 & 24.3 & 23.8 & 24 & 23.9 & 23.9 & 12.4 & 16.2 & 16.4 & 16.5 & 15.4 & 15.7 & 36.5 & 39.9 \\
\hline $\mathrm{Pr}$ & 3.21 & 3.21 & 3.42 & 3.46 & 3.36 & 3.42 & 3.41 & 3.41 & 1.83 & 2.39 & 2.41 & 2.42 & 2.22 & 2.29 & 4.69 & 5.13 \\
\hline Nd & 14.7 & 14.6 & 15.5 & 15.8 & 15.5 & 15.7 & 15.4 & 15.4 & 8.64 & 11.3 & 11.5 & 11.7 & 10.3 & 10.7 & 18.4 & 20.2 \\
\hline Sm & 3.87 & 3.94 & 4.24 & 4.29 & 4.16 & 4.2 & 4.25 & 4.18 & 2.48 & 3.24 & 3.33 & 3.37 & 2.81 & 2.92 & 3.74 & 4.13 \\
\hline $\mathrm{Eu}$ & 1.21 & 1.23 & 1.27 & 1.27 & 1.26 & 1.28 & 1.28 & 1.24 & 0.858 & 1.09 & 1.07 & 1.1 & 0.98 & 1.04 & 1.2 & 1.29 \\
\hline Gd & 4.53 & 4.46 & 4.74 & 4.71 & 4.73 & 4.67 & 4.66 & 4.73 & 2.96 & 3.87 & 3.92 & 3.96 & 3.34 & 3.52 & 3.3 & 3.59 \\
\hline $\mathrm{Tb}$ & 0.713 & 0.717 & 0.747 & 0.758 & 0.745 & 0.754 & 0.755 & 0.753 & 0.479 & 0.623 & 0.645 & 0.66 & 0.542 & 0.58 & 0.456 & 0.487 \\
\hline Dy & 4.5 & 4.55 & 4.65 & 4.77 & 4.68 & 4.85 & 4.78 & 4.78 & 3.19 & 4.08 & 4.18 & 4.23 & 3.58 & 3.77 & 2.54 & 2.84 \\
\hline Ho & 0.925 & 0.929 & 1 & 1.01 & 0.984 & 0.986 & 0.975 & 0.984 & 0.665 & 0.844 & 0.869 & 0.868 & 0.746 & 0.789 & 0.503 & 0.548 \\
\hline $\mathrm{Er}$ & 2.75 & 2.65 & 2.84 & 2.89 & 2.84 & 2.89 & 2.86 & 2.87 & 1.99 & 2.48 & 2.53 & 2.57 & 2.23 & 2.32 & 1.44 & 1.62 \\
\hline \multicolumn{17}{|l|}{$\mathrm{Tm}$} \\
\hline $\mathrm{Yb}$ & 2.53 & 2.55 & 2.64 & 2.71 & 2.64 & 2.69 & 2.65 & 2.67 & 1.87 & 2.32 & 2.36 & 2.4 & 2.13 & 2.18 & 1.39 & 1.59 \\
\hline
\end{tabular}




\begin{tabular}{|c|c|c|c|c|c|c|c|c|c|c|c|c|c|c|c|c|}
\hline & JJ1-3 & JJ1-6 & JJ1-9 & JJ1-13 & JJ1-17 & JJ1-18 & JJ1-20 & JJ1-23 & JJ3-2 & JJ3-5 & JJ3-6 & JJ3-9 & JJ4-2 & JJ4-3 & JJ2-1-10 & J22-1-14 \\
\hline Lu & 0.375 & 0.368 & 0.397 & 0.403 & 0.394 & 0.398 & 0.394 & 0.395 & 0.271 & 0.331 & 0.347 & 0.349 & 0.313 & 0.329 & 0.211 & 0.239 \\
\hline $\mathrm{Hf}$ & 2.99 & 2.92 & 3.17 & 3.18 & 3.15 & 3.15 & 3.1 & 3.12 & 1.61 & 2.18 & 2.25 & 2.27 & 1.81 & 1.87 & 2.55 & 2.81 \\
\hline Ta & 0.368 & 0.37 & 0.39 & 0.39 & 0.388 & 0.392 & 0.385 & 0.384 & 0.166 & 0.191 & 0.189 & 0.194 & 0.192 & 0.193 & 0.282 & 0.303 \\
\hline TI & 0.298 & 0.234 & 0.322 & 0.36 & 0.361 & 0.297 & 0.245 & 0.272 & 0.2 & 0.268 & 0.317 & 0.222 & 0.282 & 0.297 & 0.351 & 0.138 \\
\hline $\mathrm{Pb}$ & 9.64 & 9.7 & 10.2 & 10.5 & 10.1 & 10.2 & 10.2 & 10.1 & 6 & 9.58 & 9.9 & 9.67 & 4.63 & 4.74 & 10.9 & 12.1 \\
\hline Th & 1.98 & 1.97 & 2.07 & 2.11 & 2.06 & 2.1 & 2.08 & 2.09 & 1.03 & 1.39 & 1.4 & 1.41 & 1.19 & 1.23 & 4.46 & 4.95 \\
\hline $\mathbf{U}$ & 1.08 & 1.08 & 1.18 & 1.11 & 1.12 & 1.11 & 1.1 & 1.11 & 0.517 & 0.854 & 0.857 & 0.843 & 0.528 & 0.532 & 1.22 & 2.19 \\
\hline
\end{tabular}


Table 6 Isotopic compositions of volcanic rocks from the Cerro Amarillo and Anzó Bolombolo sections.

\begin{tabular}{|c|c|c|c|c|c|c|c|c|c|c|}
\hline & JJ1-3 & JJ1-9 & JJ1-17 & JJ1-23 & JJ3-2 & JJ3-5 & JJ3-9 & JJ4-2 & JJ2-1-10 & JJ2-1-14 \\
\hline${ }^{87} \mathrm{Sr} /{ }^{86} \mathrm{Sr}$ & 0.703911 & 0.703930 & 0.703931 & 0.703921 & 0.703916 & 0.703876 & 0.70387 & 0.703862 & 0.70417 & 0.70416 \\
\hline $2 \sigma$ & 0.000006 & 0.000008 & 0.000008 & 0.000008 & 0.000006 & 0.000006 & 0.000006 & 0.000006 & 0.000006 & 0.000006 \\
\hline $\begin{array}{l}{ }^{87} \mathrm{Sr} /{ }^{86} \mathrm{Sr} \\
\text { (leached) }\end{array}$ & 0.70391 & 0.70393 & 0.70393 & 0.70393 & 0.70392 & 0.70388 & 0.70387 & 0.70387 & 0.70417 & 0.70417 \\
\hline $2 \sigma$ & 0.000006 & 0.000006 & 0.000006 & 0.000008 & 0.000006 & 0.000006 & 0.000006 & 0.000006 & 0.000006 & 0.000006 \\
\hline${ }^{143} \mathrm{Nd} /{ }^{144} \mathrm{Nd}$ & 0.51294 & 0.51293 & 0.51292 & 0.51295 & 0.51293 & 0.51296 & 0.51293 & 0.51298 & 0.51290 & 0.51289 \\
\hline $2 \sigma$ & 0.000009 & 0.000018 & 0.000017 & 0.000010 & 0.000010 & 0.000007 & 0.000013 & 0.000008 & 0.000007 & 0.000010 \\
\hline$\varepsilon N d$ & 5.959 & 5.930 & 5.684 & 6.223 & 5.846 & 6.420 & 5.905 & 6.882 & 5.255 & 5.191 \\
\hline${ }^{208} \mathrm{~Pb} /{ }^{204} \mathrm{~Pb}$ & 38.72422 & 38.73927 & 38.73610 & 38.73702 & 38.71385 & 38.67951 & 38.68273 & 38.79674 & 38.74386 & 38.75921 \\
\hline $2 \sigma$ & 0.00418 & 0.00418 & 0.00418 & 0.00418 & 0.00418 & 0.00417 & 0.00417 & 0.00418 & 0.004179 & 0.004180 \\
\hline${ }^{207} \mathrm{~Pb} /{ }^{204} \mathrm{~Pb}$ & 15.61989 & 15.62459 & 15.62410 & 15.62365 & 15.62449 & 15.61989 & 15.62098 & 15.61286 & 15.60328 & 15.61037 \\
\hline $2 \sigma$ & 0.00167 & 0.00167 & 0.00167 & 0.00167 & 0.00167 & 0.00167 & 0.00167 & 0.00167 & 0.001668 & 0.001669 \\
\hline${ }^{206} \mathrm{~Pb} /{ }^{204} \mathrm{~Pb}$ & 18.96667 & 18.97333 & 18.97308 & 18.97264 & 18.93568 & 18.91002 & 18.91054 & 19.06522 & 19.00789 & 19.018005 \\
\hline $2 \sigma$ & 0.00365 & 0.00365 & 0.00365 & 0.00365 & 0.00365 & 0.00364 & 0.00364 & 0.00367 & 0.003662 & 0.003666 \\
\hline
\end{tabular}


Table 7 Estimated isotopic compositions and parameters for end-member involved in magma genesis $\begin{array}{lllllll}{ }^{208} \mathrm{~Pb} /{ }^{204} \mathrm{~Pb} & { }^{206} \mathrm{~Pb} /{ }^{204} \mathrm{~Pb} & \mathrm{~Pb}(\mathrm{ppm}) & { }^{142} \mathrm{Nd} /{ }^{144} \mathrm{Nd} & \mathrm{Nd}(\mathrm{ppm}) & { }^{87} \mathrm{Sr} /{ }^{86} \mathrm{Sr} & \mathrm{Sr}(\mathrm{ppm})\end{array}$

\begin{tabular}{|c|c|c|c|c|c|c|c|}
\hline$A O C^{1,9}$ & 38.14 & 18.59 & 0.53 & 0.51280 & 4.71 & 0.70381 & 61.40 \\
\hline $\mathrm{HS}^{2,3,4}$ & 38.86 & 18.64 & 9.59 & 0.51247 & 17.0 & 0.70763 & 336.16 \\
\hline $\mathrm{CS}^{2,3,4,5}$ & 38.16 & 18.46 & 3.70 & 0.51242 & 0.89 & 0.70858 & 1504.12 \\
\hline SC_1 ${ }^{*}$ & 38.62 & 18.62 & 1.43 & 0.51285 & 5.94 & 0.70454 & 75.138 \\
\hline SC_2 ${ }^{*}$ & 38.57 & 18.60 & 1.54 & 0.51284 & 1.15 & 0.70661 & 146.412 \\
\hline$M W^{6,7}$ & 37.90 & 18.50 & 0.02 & 0.51310 & 0.71 & 0.70270 & 9.80 \\
\hline PM* & 38.45 & 18.59 & 0.82 & 0.51307 & 5.81 & 0.70469 & 114.95 \\
\hline $\mathrm{LCC}^{8}$ & 38.73 & 19.02 & 8.81 & 0.51309 & 9.50 & 0.70423 & 173.00 \\
\hline
\end{tabular}

* Estimated values. Kd from Halliday et al. (1995). AOC: Altered oceanic crust; HS: Hemipelagic sediments; CS: Carbonaceous sediments; SC_1: Subduction component 1 (AOC+HS); SC_2: Subduction component 2 (SC_1 + CS); MW: Mantle wedge (5\%cpx, 25\%opx, 70\%ol); PM: Primary magma; and LCC: Lower continental crust. Values are calculated based on procedures followed by Marín-Cerón (2007) for the SW Colombian volcanic arc. Values for AOC, HS, CS, MW, and LCC, are given according to data presented by Marín-Cerón (2007). SC_2 represents the interaction between $\mathrm{AOC}(85 \%)$ and sediments ( $\mathrm{HS}-10 \%$ and CS - 5\%). PM is calculated assuming $40 \%$ of metasomatized mantle by subduction component. It is considered $10 \%$ of LCC interacts with primary magma for magma source genesis. ${ }^{1}$ Pedersen et al. (2001); ${ }^{2}$ Plank and Langmuir (2000); ${ }^{3}$ Patiño et al. (2000); ${ }^{4}$ Vervoort et al. (1999); ${ }^{5}$ Hemming and McLennan (2001); ${ }^{6}$ Salters and Stracke (2004); ${ }^{7}$ Saunders et al. (1988); ${ }^{8}$ Weber et al. (2002); ${ }^{9}$ Barret (1983); and ${ }^{10}$ Halliday et al. (1995). 


\section{Lithological units}

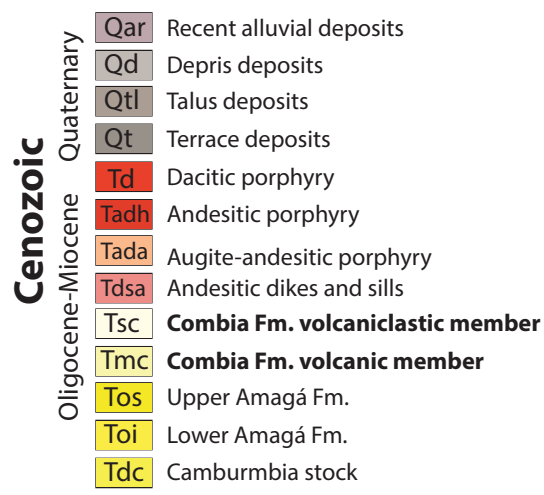

\footnotetext{
Kcdu Ursula stock

Kgh Hispania gabbro

Kg Gabbro

Ksga Altamira gabbro

$气$ Ksta Antioquia batholith

Kodha Heliconia quartzdiorite

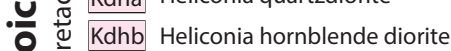

Kvb Barroso Fm.

Kvc Quebradagrande Fm. volcanic memeber

KsC Quebradagrande Fm. sedimentary memeber

Kuh Ultramafic harzburgite

Kaa Penderisco Fm

Kida Altavista batholith

Jus Ultramafic rocks

đJgr Roneral gabbro

き Jdp Pueblito diorite

TRa Amagá stock

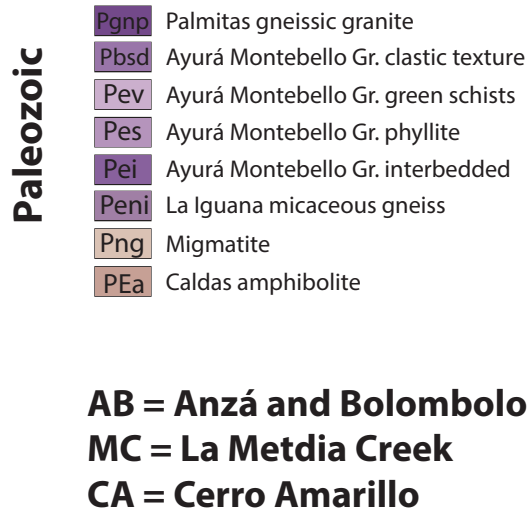

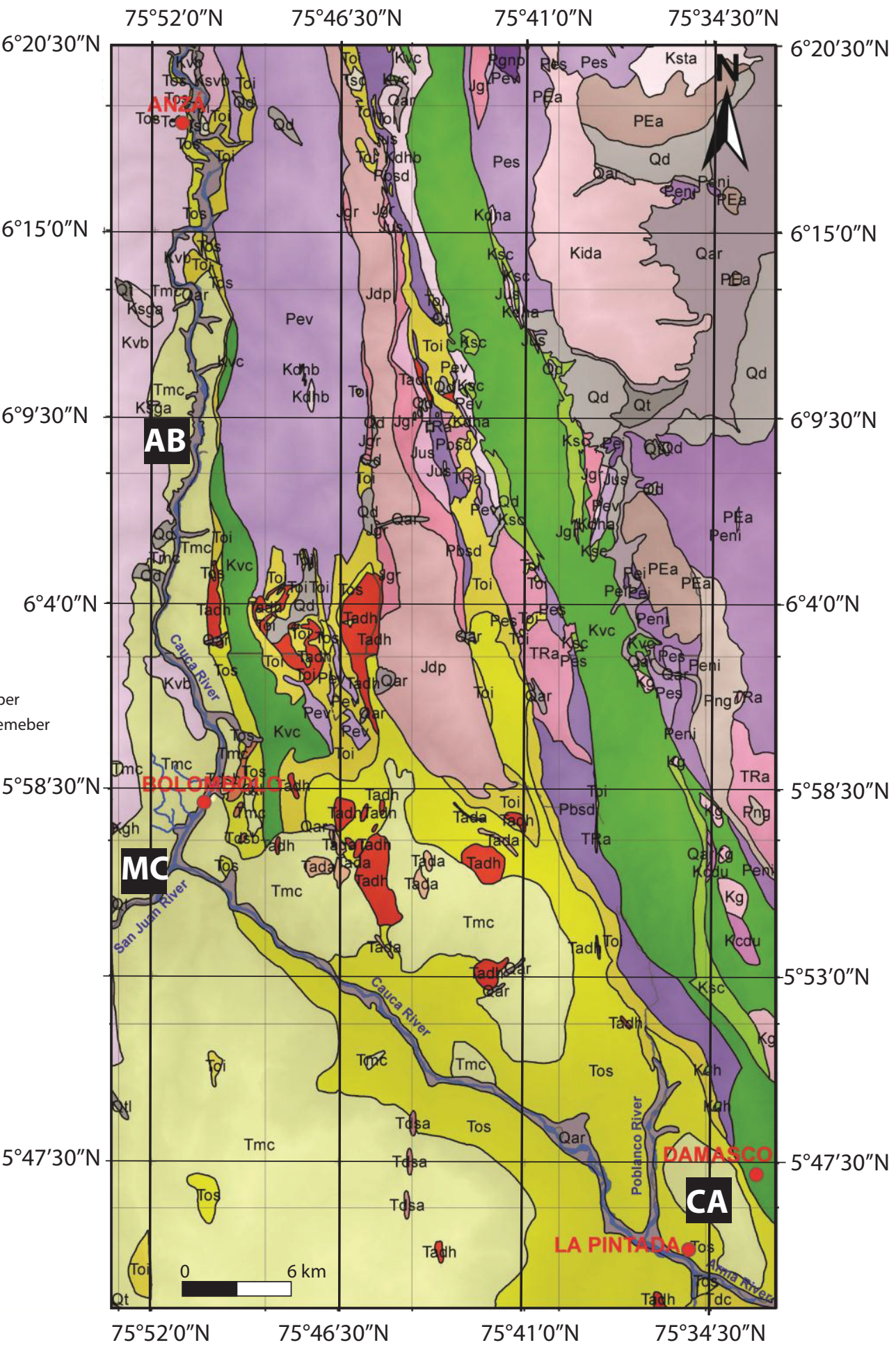

Fig. 2 Bernet et al. 


\section{CERRO AMARILLO SECTION}

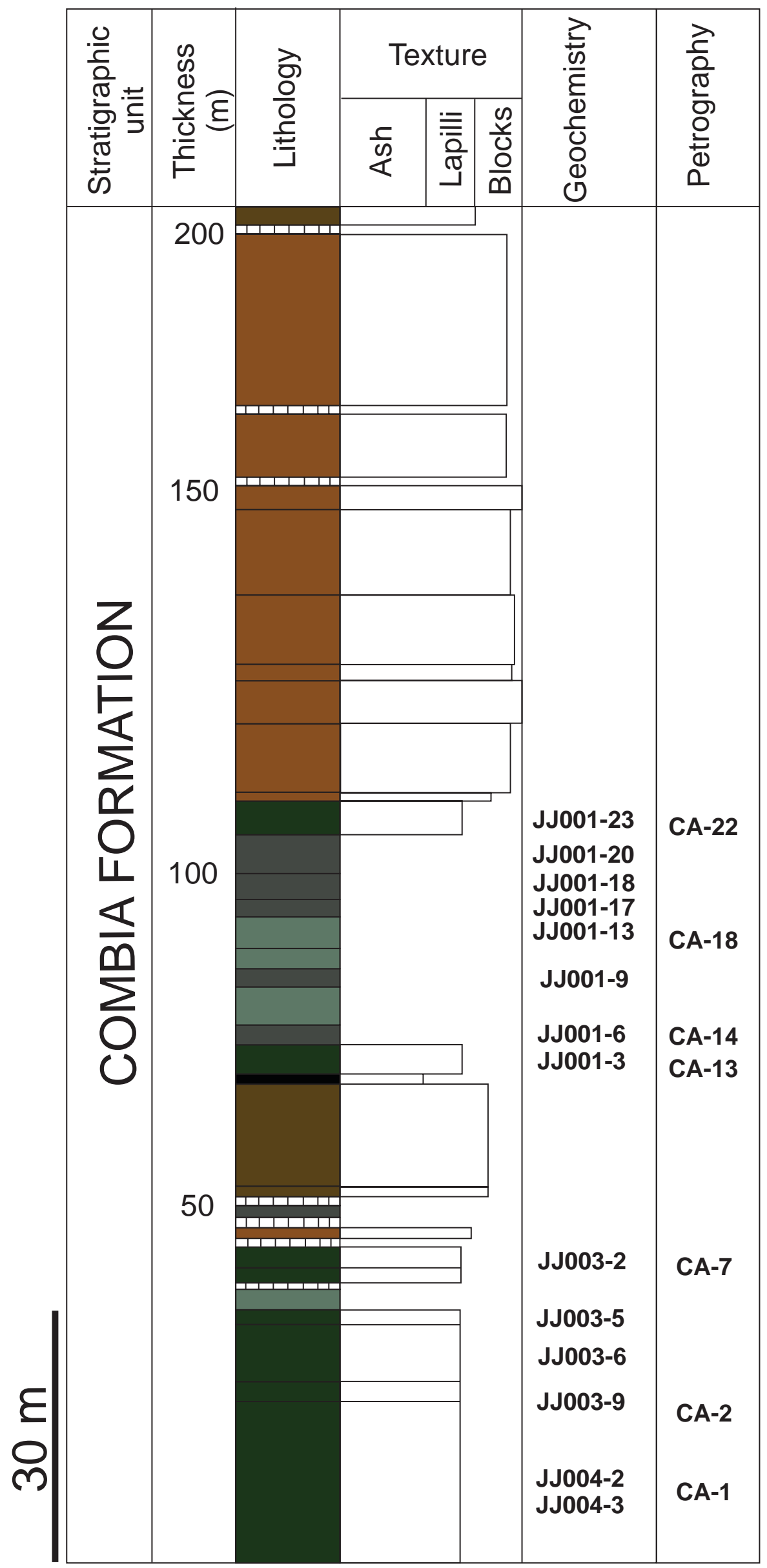

Pyroclastic breccia

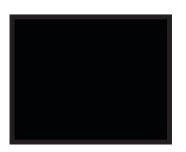

Scoria

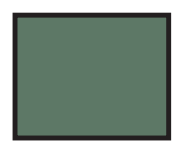

Vesicular basaltic andesite

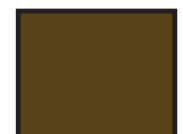

Lapilli tuff breccia

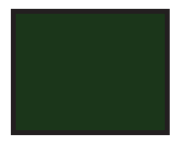

Ignimbrite

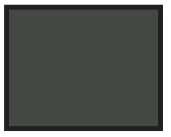

Basaltic andesite

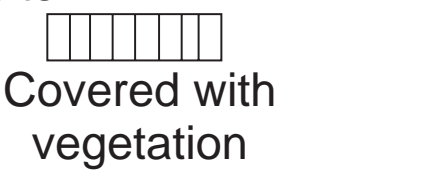

Fig. 3 Bernet et al. 
ANZA - BOLOMBOLO SECTION

Trachy-andesite and pyroclastic sequence

Tuffaceous sequence
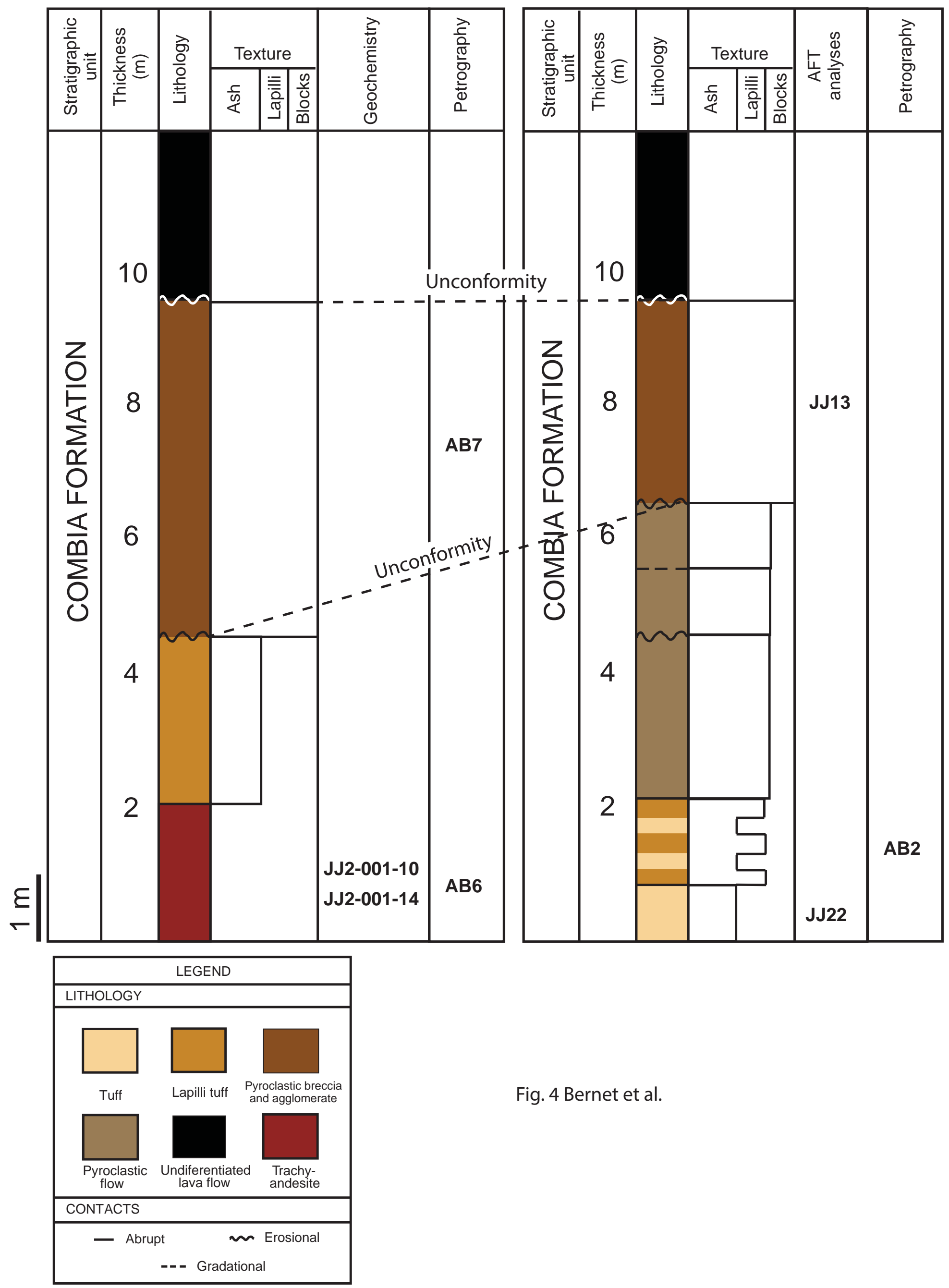

Fig. 4 Bernet et al. 
LA METIDA CREEK SECTION

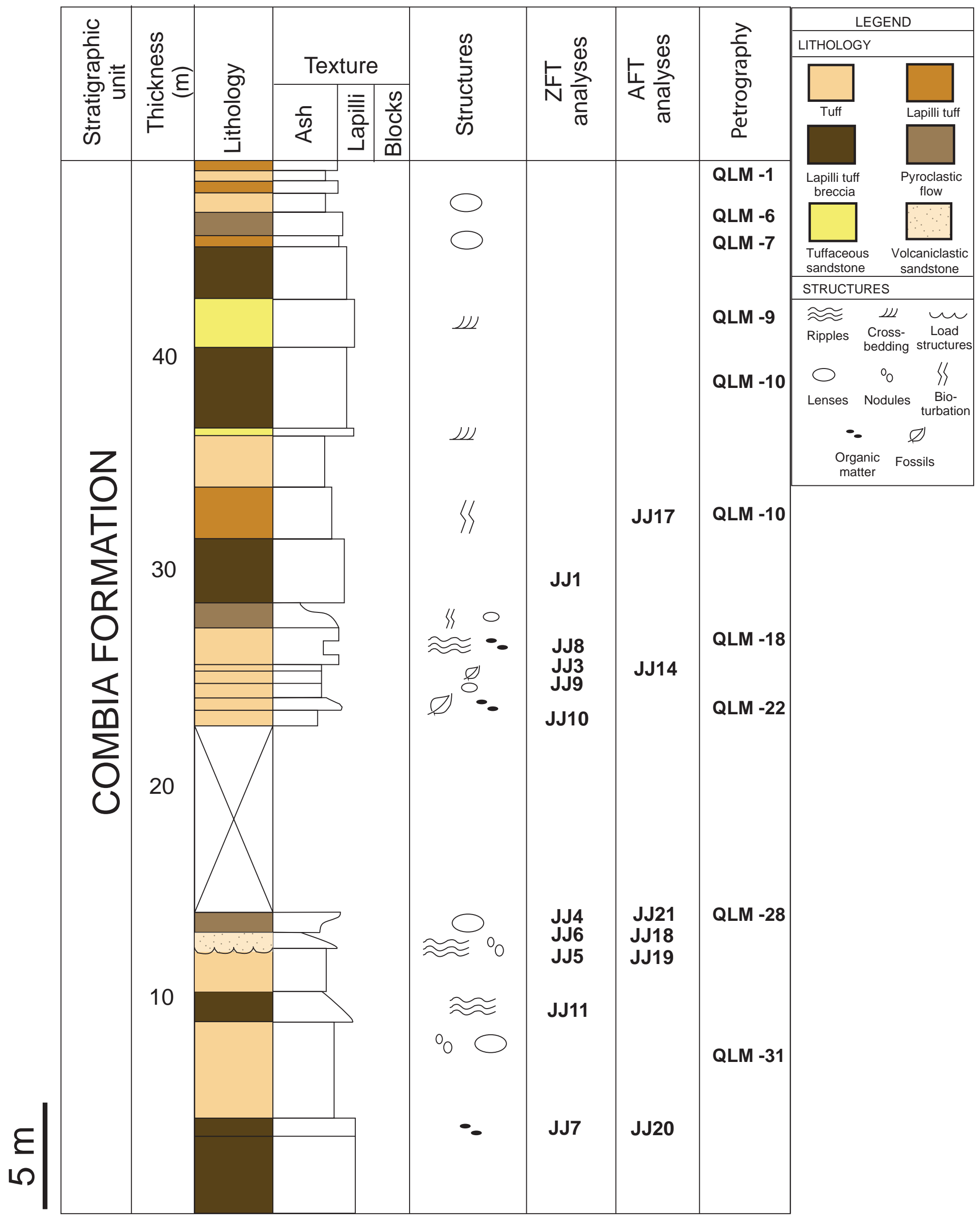

Fig. 5 Bernet et al. 
Combia Formation combined AFT data $(n=302)$

Central age $=8.54 \pm 0.66 \mathrm{Ma}(1 \sigma)$

Dispersion $=52 \%$

$\mathrm{P}\left(\mathrm{X}^{2}\right)=0.00$
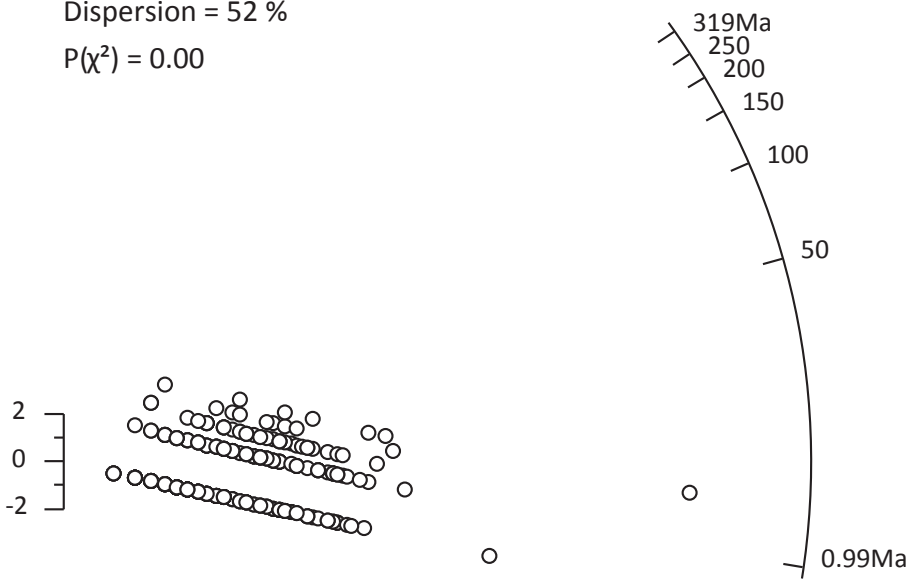

Combia Formation combined ZFT data $(n=346)$

Central age $=9.1 \pm 0.24 \mathrm{Ma}(1 \sigma)$

Dispersion $=34 \%$

$\mathrm{P}\left(\mathrm{X}^{2}\right)=0.00$

2
0
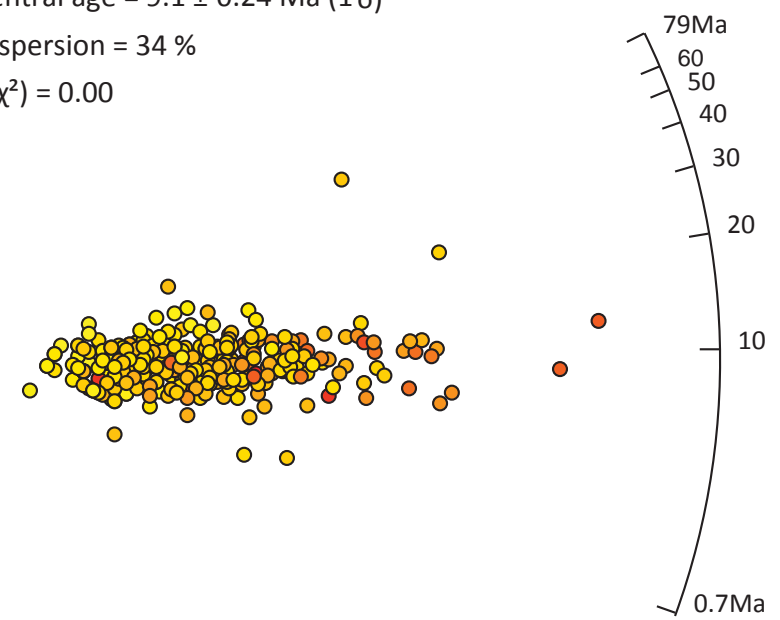
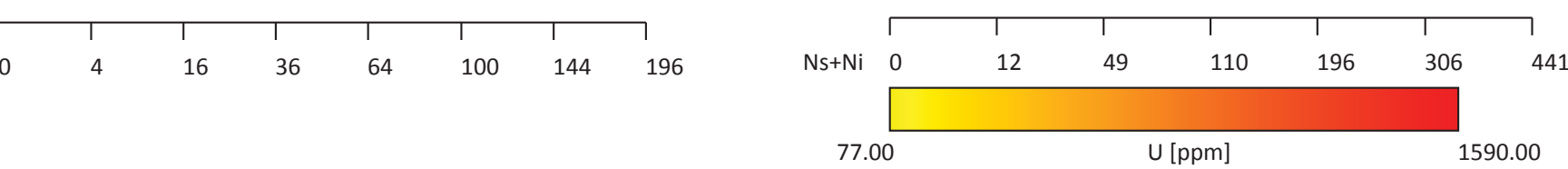

Fig 6 Bernet et al. 
A)

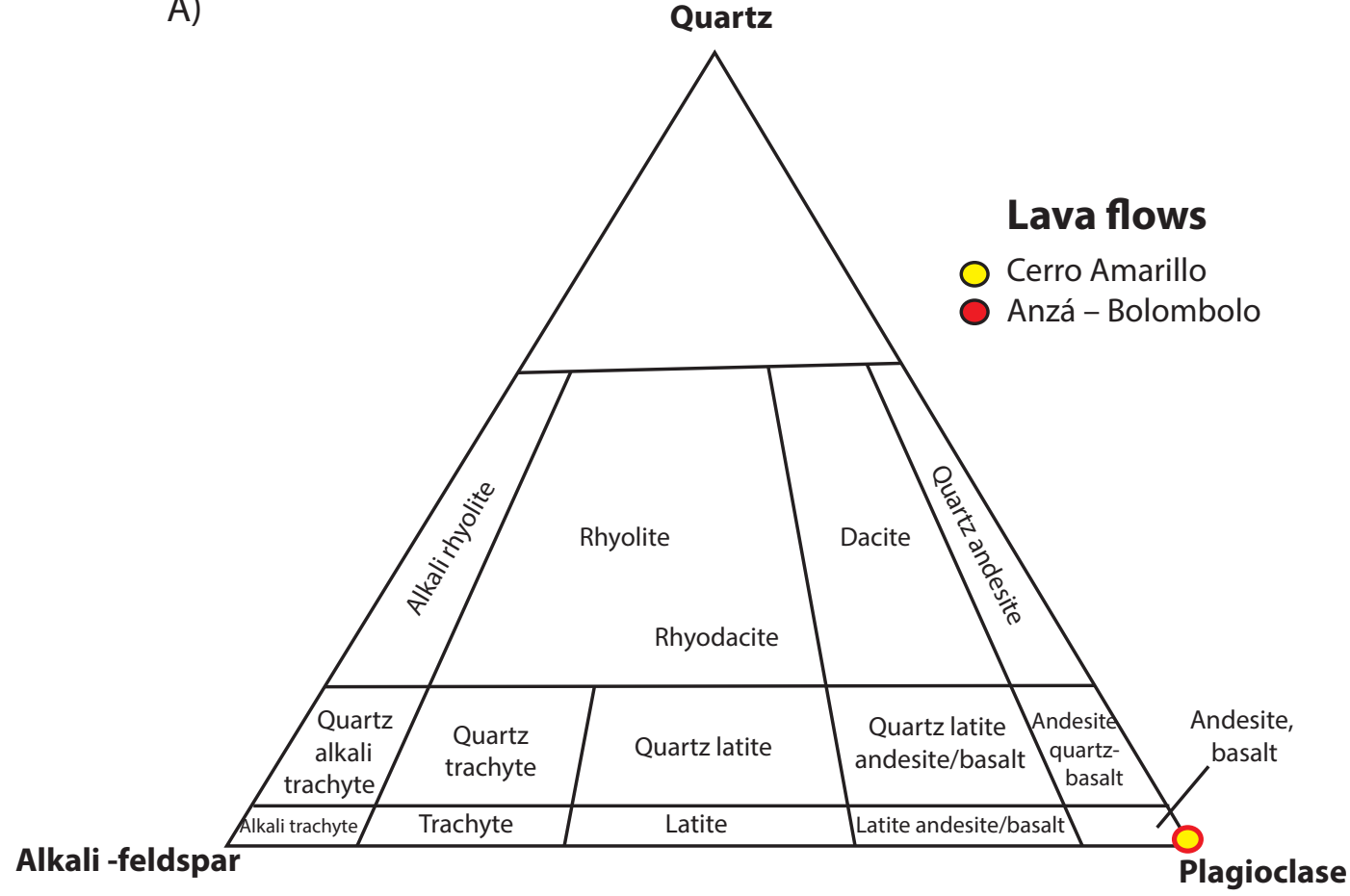

B)

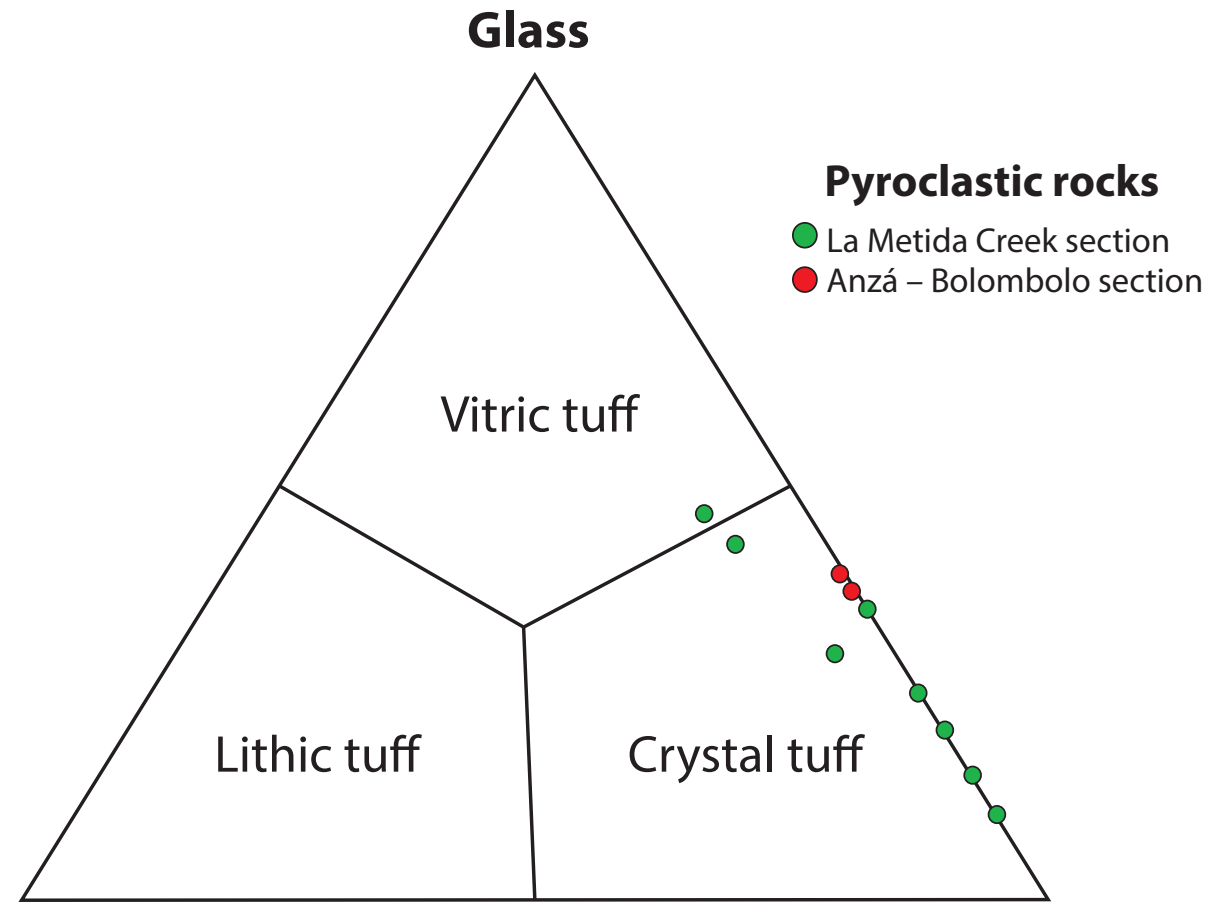

Rock fragments

Crystals

Fig 7 Bernet et al. 

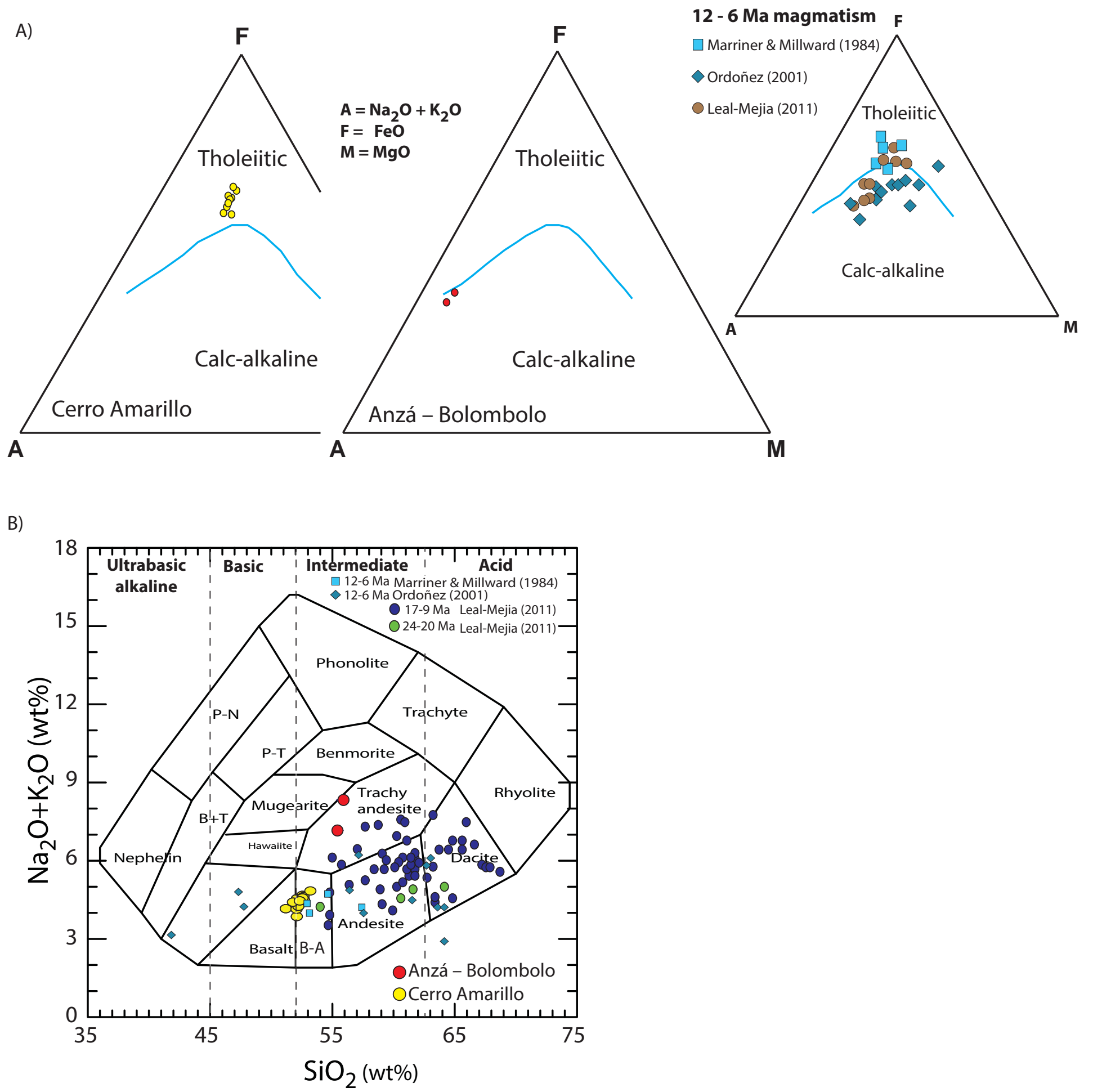

Fig. 8 Bernet et al. 
A)

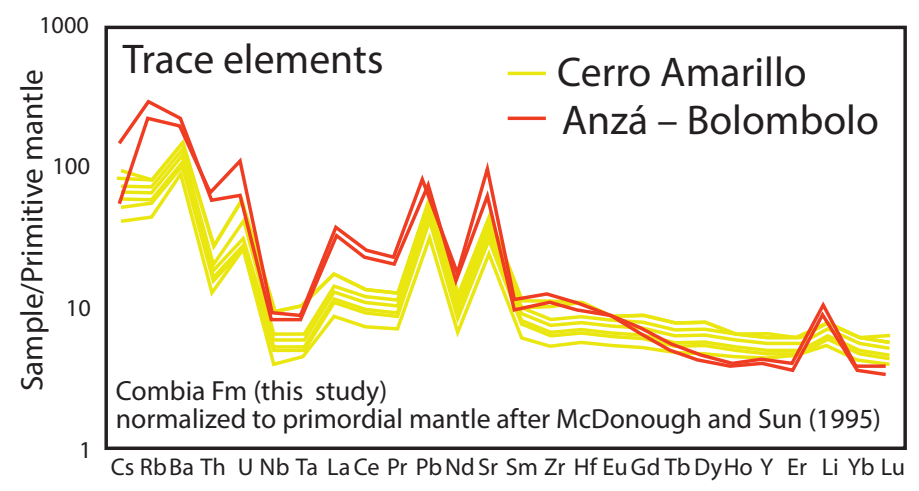

C)

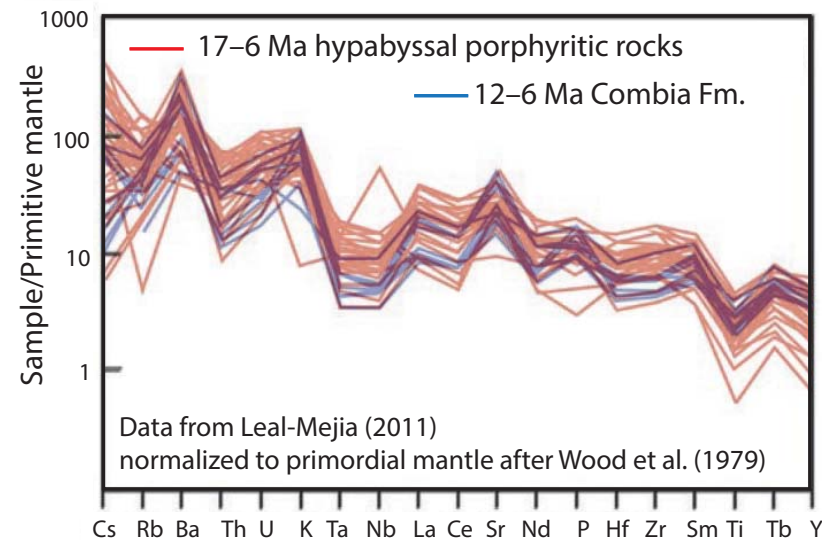

E)

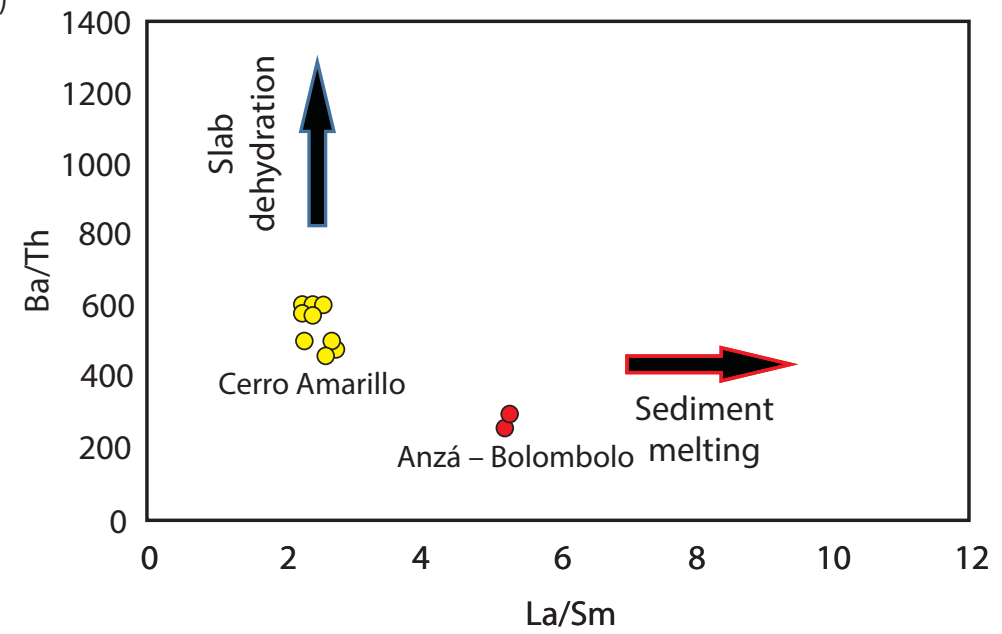

B)

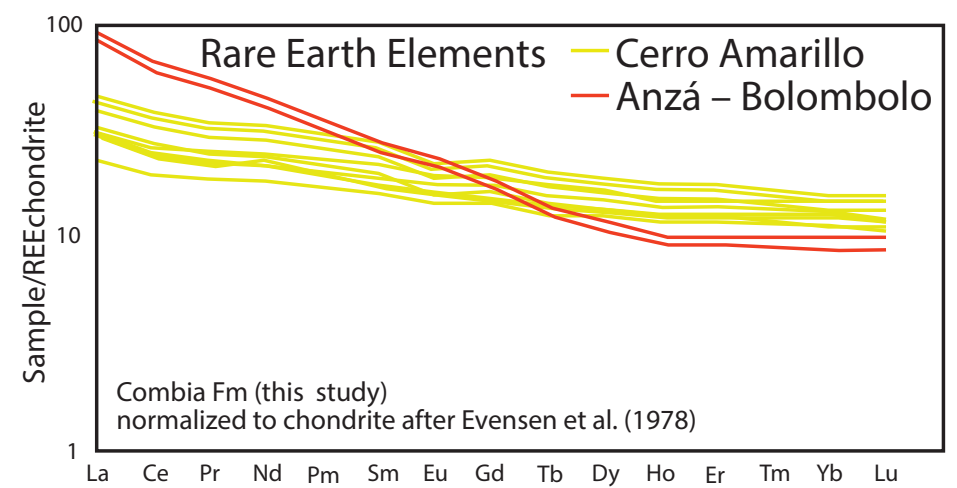

D)

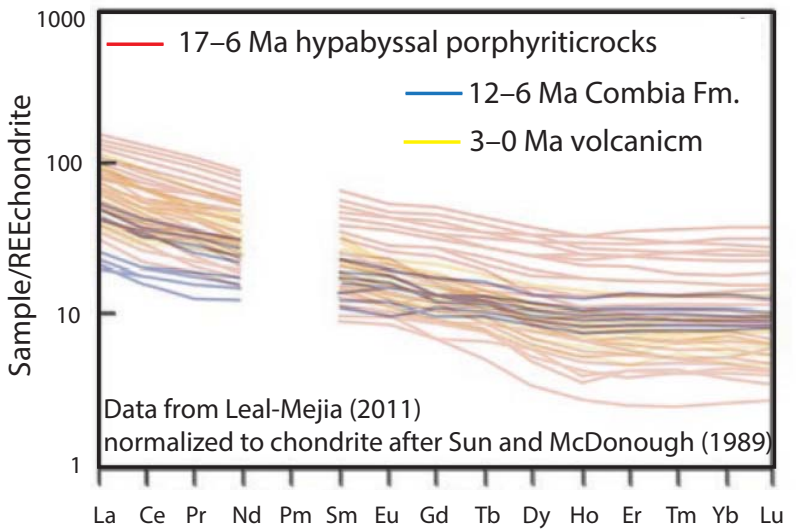

Fig. 9 Bernet et al. 
A)

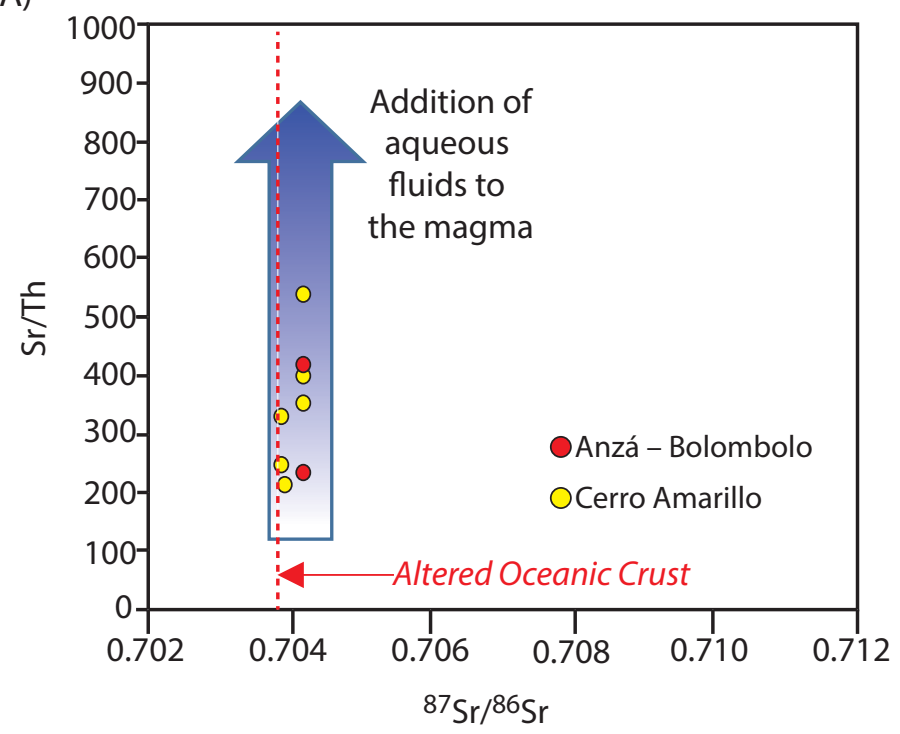

B)

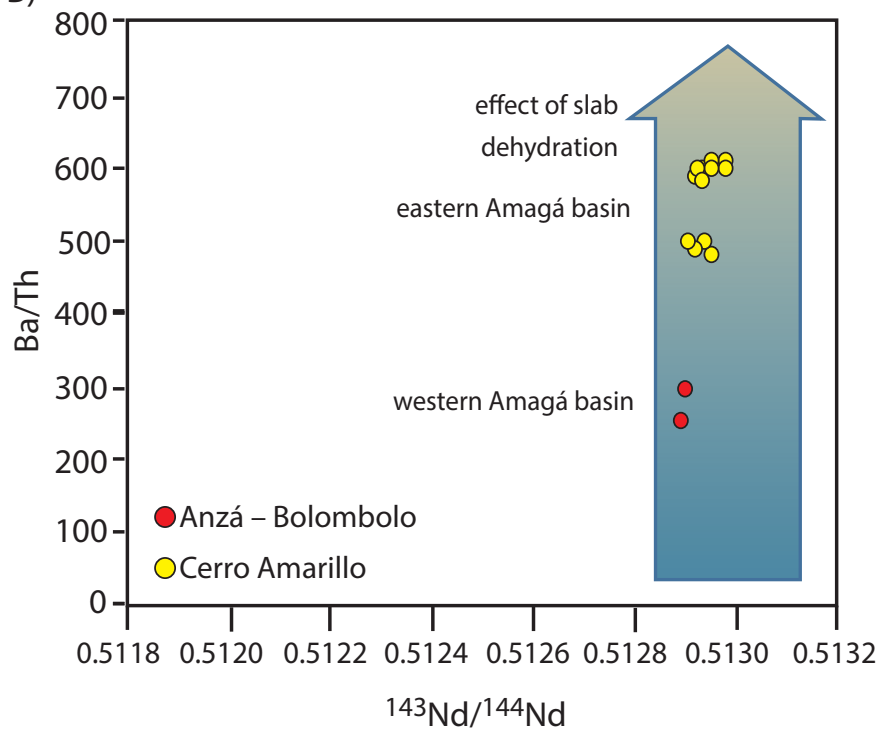

C)

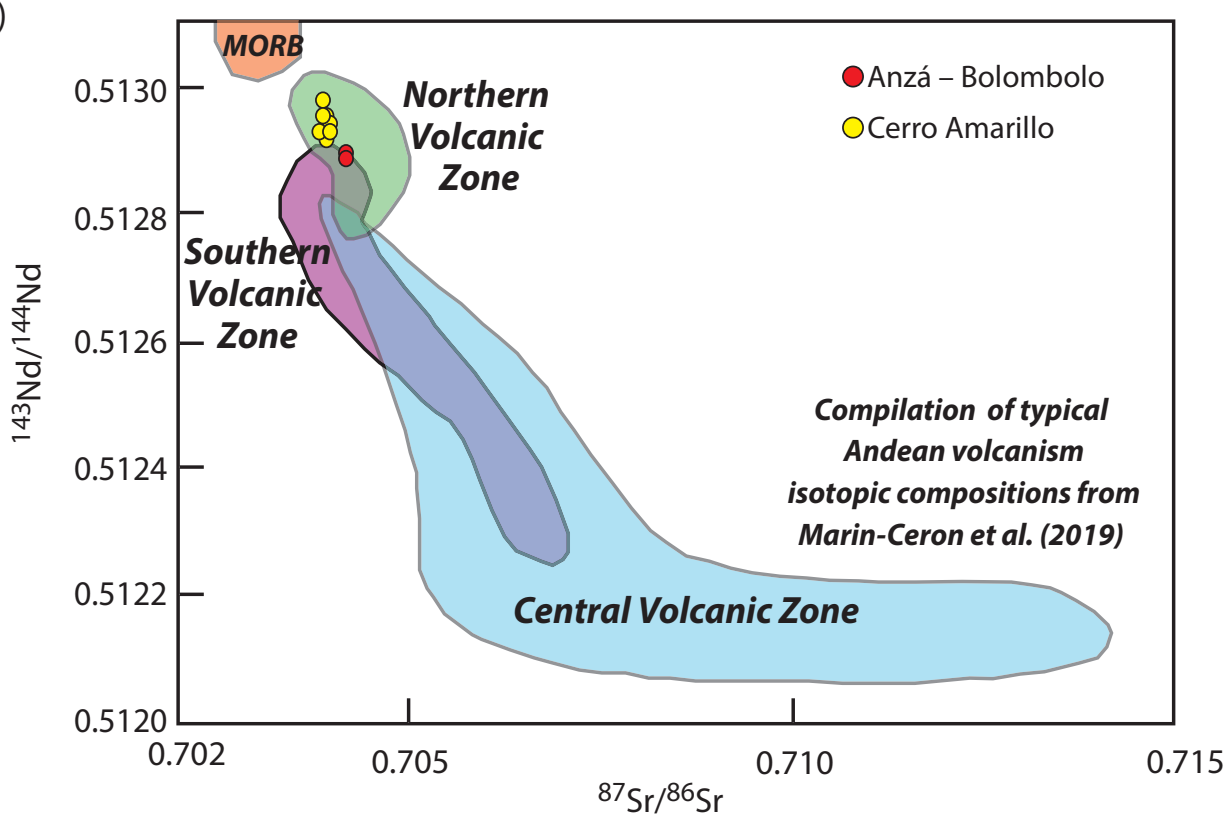

Fig 10 Bernet et al. 
A)

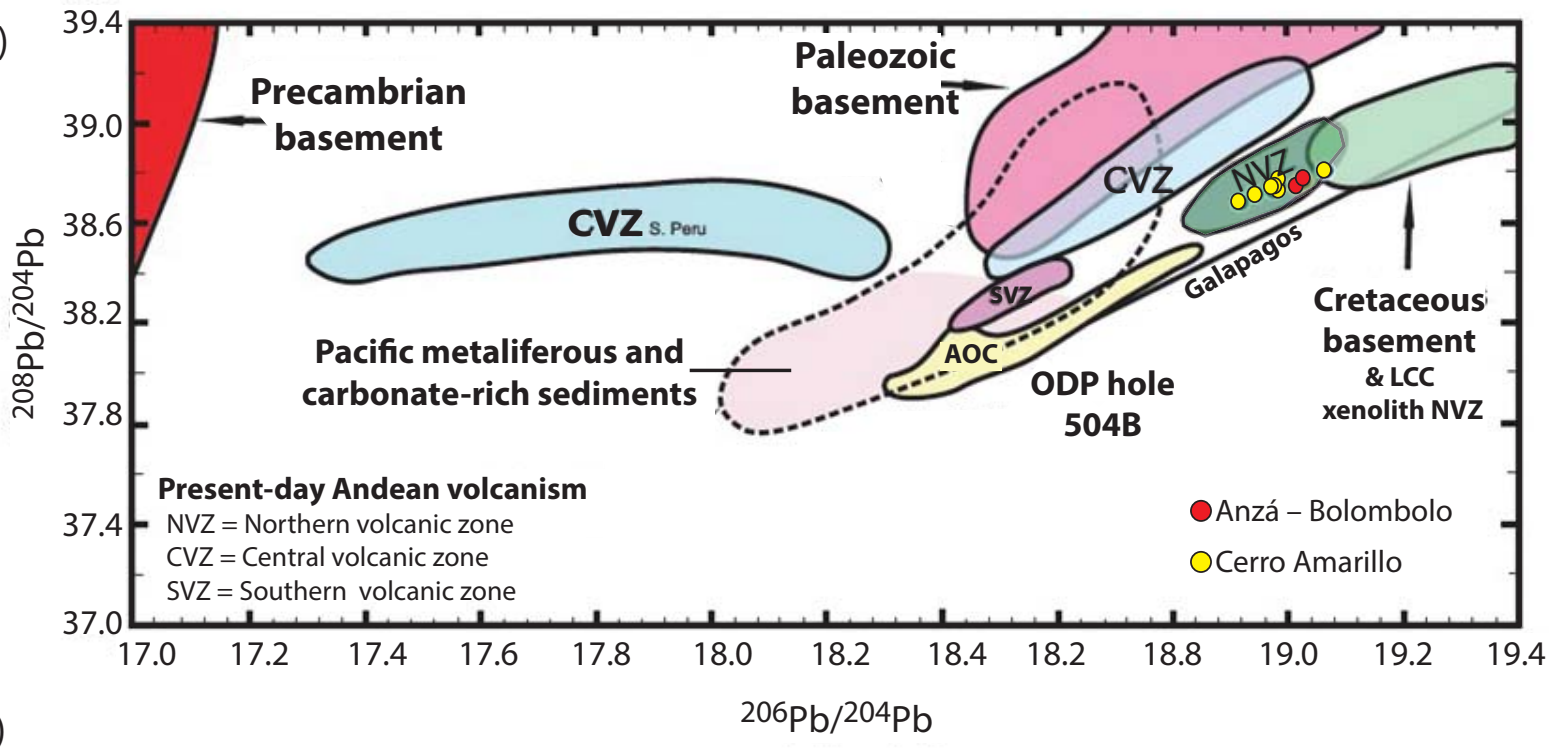

B)

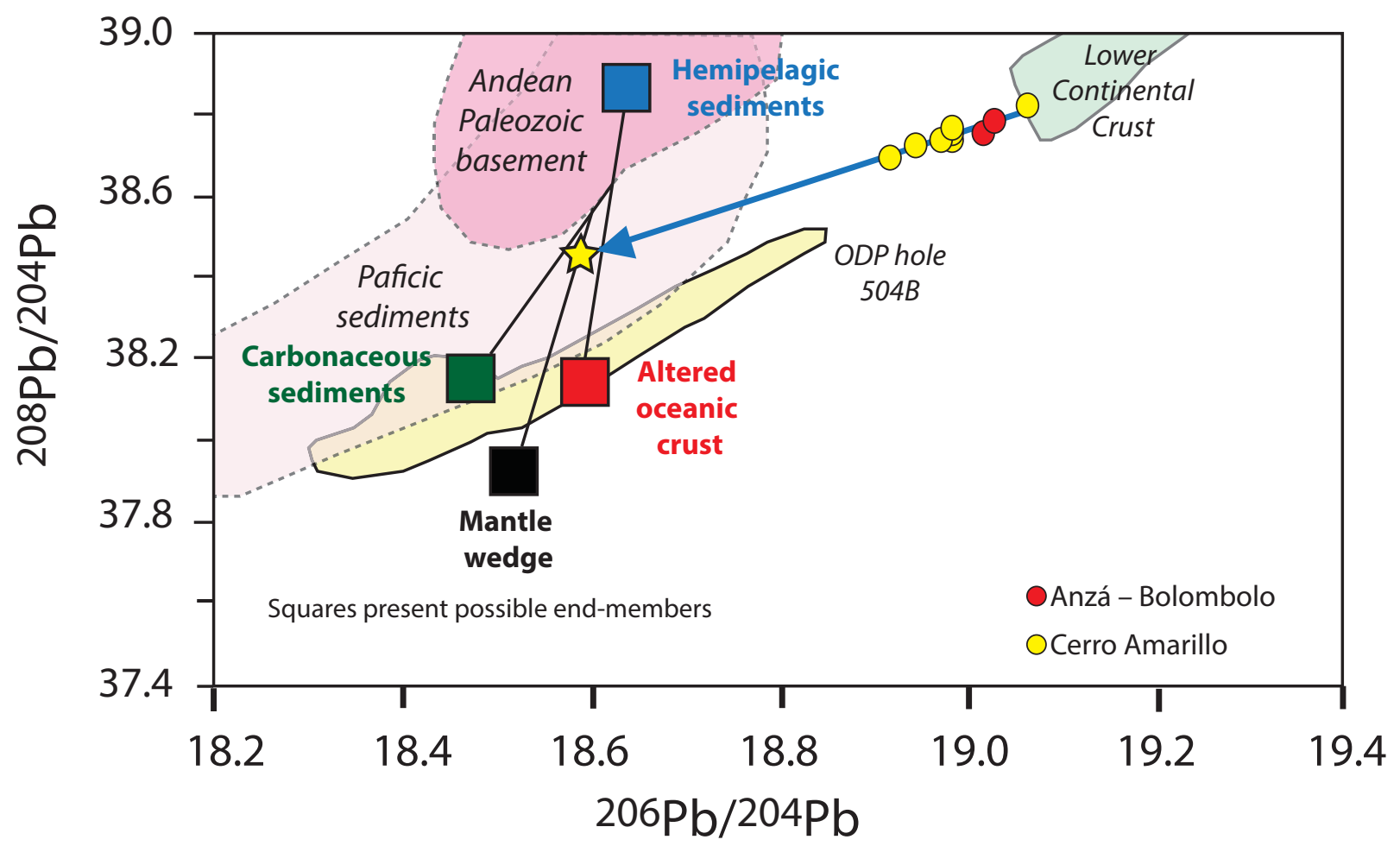

Fig. 11 Bernet et al. 


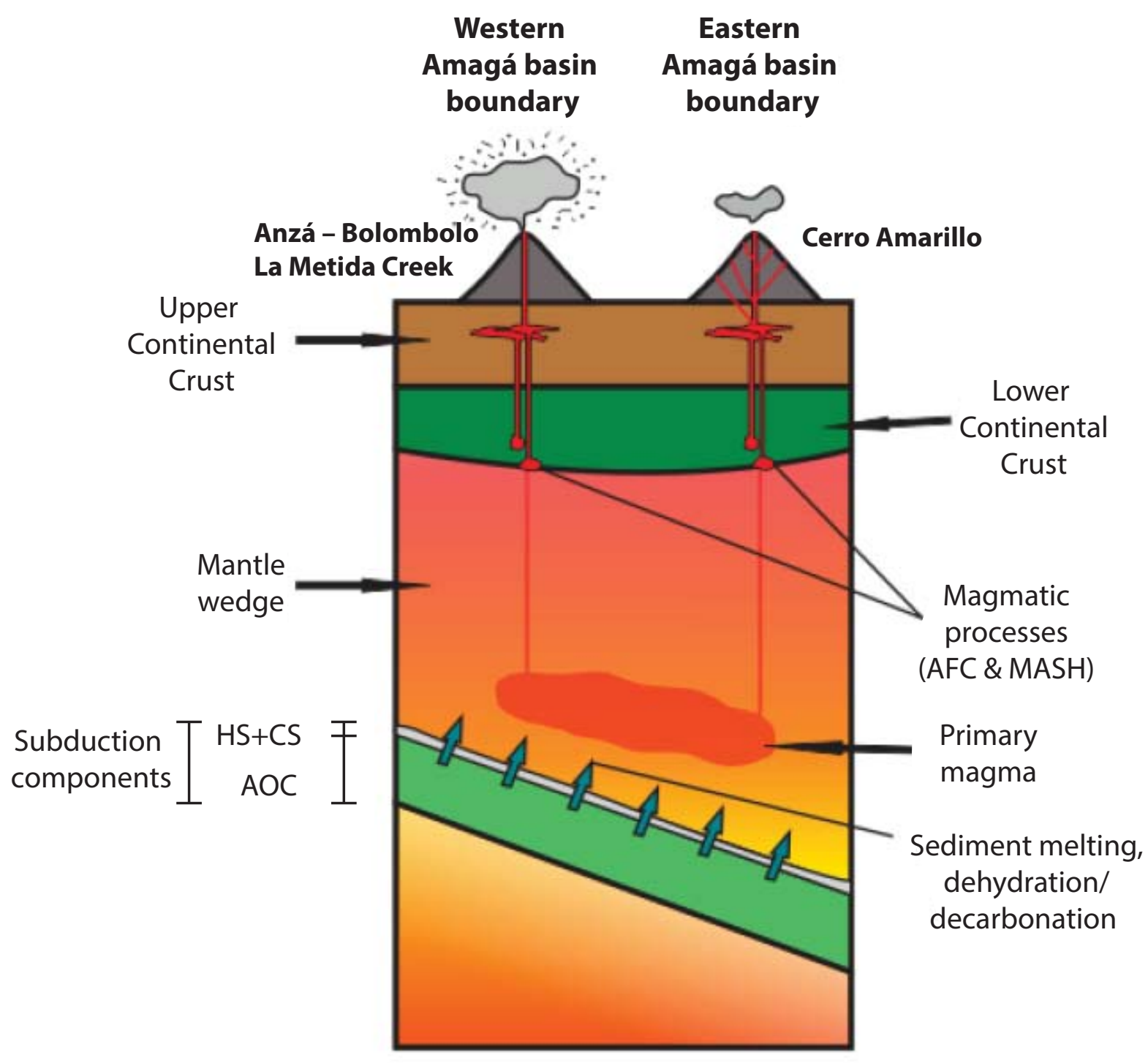

Fig. 12 Bernet al. 